\title{
PROMOTING THE RULE OF LAW IN THE EU ENLARGEMENT POLICY: A TWOFOLD CHALLENGE
}

\author{
Leposava Ognjanoska*
}

\begin{abstract}
Since the rule of law was introduced into the EU enlargement policy, its role within the conditionality policy has advanced gradually so that it has become the cornerstone of the accession process. This paper analyses the evolution of the rule of law promotion in the process of EU enlargement with a focus on the Western Balkans and strives to identify what the main challenges are in this regard and the main reasons why the EU has made the rule of law central to its new enlargement methodology. Drawing on the experience of the Europeanisation process of the CEE countries, the paper examines the different approaches in terms of the promotion of the rule of law within the Copenhagen political accession criteria. It finds that with regard to the accession process of the Western Balkans, the EU is no longer satisfied with 'reforms on paper' and strives to apply more active leverage. However, the internal challenges for the rule of law within the EU and the often 'neglected' fourth Copenhagen criterion - absorption capacity of the Union itself referring to its capability to include new members - also affect the process. Rule of law conditionality has been compromised not only by more focus on the box-ticking benchmark fulfilment exercise than on substance, but also by the lack of credibility on the side of the EU that has undermined the pre-accession conditionality. The most illustrative case in this regard is the accession process of North Macedonia that is analysed as a case study in order to identify the main challenges and shortcomings of the EU enlargement policy. The paper proposes that the rule of law promotion and the overall Europeanisation process must rest on a credible merit-based accession process that involves clear commitments on both sides - candidate countries but also the EU.
\end{abstract}

Keywords: European Union, rule of law, enlargement policy, conditionality, accession process, Western Balkans.

\footnotetext{
" $\mathrm{PhD}$ candidate at the Faculty of Law "Iustinianus Primus" - Ss Cyril and Methodius University in Skopje (ORCID iD: 0000-0002-3599-4493, lea.ognjanoska@gmail.com). Research for this paper was completed under the supervision of Professor Julija Brsakoska-Bazerkos$\mathrm{ka}$, as part of the process of preparing a doctoral thesis, to whom I am particularly grateful for all the motivation and support. I would also like to thank the CYELP Editorial Board for all the help along the way, as well as the two anonymous reviewers for their thoughtful comments and efforts towards improving the article. DOI: 10.3935/cyelp.17.2021.455.
} 


\section{Introduction}

The EU is not only a 'Community based on the rule of law' but it is a Community/Union based solely or at least primarily on the rule of law. ${ }^{1}$ The rule of law is enshrined at the core of European Union primary law - it is listed among the founding values of the Union and is stated as an objective that determines the way in which the EU exercises its competencies. ${ }^{2}$ According to Article 2 TEU, the EU is founded on a set of values, one of which is the rule of law. Not only is the rule of law the pillar on which the Union is based, but it upholds all the other values and principles. ${ }^{3}$ Likewise, it is also recognised as a value defining EU membership, given Article 49 TEU which stipulates that every European state that respects the values referred to in Article 2 (basic values of the EU) and is committed to their promotion may apply to become a member of the EU. Hence, the enlargement of the Union is based on achieving and respecting certain values: the fundamental values of the EU including the rule of law. On the other hand, the rule of law must not only be respected for a state to become and remain a member of the EU, but it must also be actively promoted - Article 3(1) TEU foresees that the Union is to promote its values and the well-being of its citizens. The special Eurobarometer on the rule of law (April 2019) ${ }^{4}$ showed overwhelming popular support for this value among EU citizens.

Even lacking an express reference in the early versions of the Treaties establishing the European Community (TEC) and the European Union (TEU), before being acknowledged as the Union's founding principles with the Treaty of Amsterdam, the rule of law, human dignity, freedom, democracy, equality and human rights were well established in the Community's political and judicial practice. Development and consolidation of democracy and the rule of law were already promoted as general objectives of the Common Foreign and Security Policy under the Maastricht Treaty (1992) and were required by the Copenhagen Criteria (known as the Accession Criteria from 1993). Article 49 TEU is an implicit

\footnotetext{
${ }^{1}$ Frank Emmert, 'Rule of Law in Central and Eastern Europe' (2008) 32(2) Fordham International Law Journal 551, 582.

${ }^{2}$ Christophe Hillion, 'Overseeing the Rule of Law in the European Union: Legal Mandate and Means' [2016] European Policy Analysis 1.

${ }^{3}$ As Commissioner Barroso stated in March 2014, on introducing the new framework for safeguarding the rule of law in the European Union, see 'European Commission Presents a Framework to Safeguard the Rule of Law in the European Union' (Strasbourg, 11 March 2014) <https://ec.europa.eu/commission/presscorner/detail/en/IP_14_237> accessed 19 May 2021.

${ }^{4}$ European Commission, Special Eurobarometer 489 Report - Rule of Law, April 2019, doi:10.2838/403530_<https://ec.europa.eu/commfrontoffice/publicopinion/index.cfm/ survey/getsurveydetail/instruments/special/surveyky/2235> accessed 19 May 2021.
} 
reflection of the 1993 Copenhagen (political) criteria that set the ground for the conditionality policy as a framework for EU accession of the Central and Eastern European states (CEE). The EU Eastern enlargement in 2004 which continued with the accession of Bulgaria and Romania in 2007 represents a milestone in the evolution of European integration seen as a tool to consolidate democratic transition and strengthen civil and political freedoms and rights in the post-communist states in their 'ideological return' to Europe.

Enlargement policy unites foreign policy, assistance, and conditionality in a package of tools and incentives where the accession process needed to adapt in order to foster the transformative power of the EU with regard to the candidate states. Introducing the Copenhagen criteria within the conditionality policy meant placing certain key areas such as the rule of law high on the enlargement agenda, as the progress of countries towards full membership in the EU was to depend on their performance in a wide range of reforms regarding the economy, standards of democracy, human rights, good governance and respect for the rule of law. The conditionality policy was used as a crucial mechanism by the EU to make countries accept the rules set as conditions which the applicant country has to fulfil in order to receive rewards. ${ }^{5}$ Therefore, compliance with the set rules prior to accession is mainly driven by rational cost-benefit calculations and actors in pursuit of maximising their own power, which proves the rational institutionalism theory. ${ }^{6}$ The experience from this enlargement, especially the negotiations with Bulgaria and Romania, had a significant impact on the development of the negotiation structure. Accession negotiations with these two states showed that shortcomings in key areas such as the judiciary and the fight against corruption had not been entirely overcome, while this incentive-based model does not contain guarantees for compliance with EU law in the post-accession period.

The European Union introduced a distinction between the Western Balkan and Central and East European (CEE) countries, a distinction also reflected in the accession process. At the Thessaloniki Summit in June 2003, unambiguous support for the European perspective of the Western Balkan states was declared, stating that 'the future of the Bal-

\footnotetext{
${ }^{5}$ Frank Schimmelfennig, Stefan Engert and Heiko Knobel, 'Costs, Commitment and Compliance: The Impact of EU Democratic Conditionality on Latvia, Slovakia and Turkey' (2003) 41(3) Journal of Common Market Studies 495, 496.

${ }^{6}$ See Florian Trauner 'Post-accession Compliance with EU Law in Bulgaria and Romania: A Comparative Perspective' in Frank Schimmelfennig and Florian Trauner (eds), Post-accession Compliance in the EU's New Member States (2009) 13(2) European Integration online Papers EIoP Art 21.
} 
kans is in the European Union', ${ }^{7}$ while the term 'European perspective' meant membership and full inclusion in the EU institutional and political structure. ${ }^{8}$ In the 2005 Enlargement Strategy, the Commission introduced a reinforced monitoring system with regard to the rule of law into the accession process for every Western Balkan state. ${ }^{9}$ According to the conclusions of the European Council Summit in Brussels in 2006, the updated consensus on the enlargement process enhanced the importance of the rule of law in the accession process. ${ }^{10}$ This approach was characteristic of the accession negotiations with Croatia that were finalised in June 2011 whereby the country became the newest EU Member State in 2013. Apart from Croatia, eighteen years after the Thessaloniki Summit, Albania, Bosnia and Herzegovina, Kosovo, Macedonia, Montenegro and Serbia are still far away from full EU membership. Since the rule of law was introduced into the accession process, its role within the conditionality policy has advanced gradually so that it became the cornerstone of the EU-Western Balkans Strategy of $2018^{11}$ and the new Methodology for accession negotiations of 2020. ${ }^{12}$

Nevertheless, this new Methodology is still not implemented within the accession process of North Macedonia and Albania and, instead of providing credibility, it has brought more uncertainty and unpredictability. Credibility refers to the EU's readiness to withhold the reward if conditions are not met, but also to deliver on the promise once they are. This paper analyses the evolution of the rule of law promotion in the process of EU enlargement, with a focus on the Western Balkans, and strives to identify what the main challenges are in this regard and the main reasons why the EU has made the rule of law central to its new enlargement methodology. The main argument in this regard is that the EU increasingly applies strengthened conditionality and is no longer satisfied with 'reforms on paper', due to the lessons learned from the accession process itself and the complex system in the Western Balkan states but also the internal challenges for the rule of law within the EU and the often 'neglected' fourth Copenhagen criterion - the absorption capacity of the Union itself, referring to its capability to include new members. The analysis proceeds according to the following three steps:

\footnotetext{
${ }^{7}$ European Council, Presidency Conclusions, Thessaloniki, 19 June 2003.

${ }^{8}$ Commission, 'The Western Balkans and European Integration' (Communication) COM (2003) 285.

${ }^{9}$ Commission, '2005 Enlargement Strategy Paper' (Communication) COM (2005) 561.

${ }^{10}$ European Council, Presidency Conclusions, Brussels, 15 December 2006.

${ }^{11}$ Commission, 'A Credible Enlargement Perspective for and Enhanced EU Engagement with the Western Balkans' (Communication) COM (2018) 65.

12 Commission, 'Enhancing the Accession Process - A Credible EU Perspective for the Western Balkans' (Communication) COM(2020) 57.
} 
firstly, the Europeanisation process in Central and Eastern Europe is reviewed and discussed in view of the guiding research interest, together with the post-accession attitude. Secondly, the paper analyses the EU promotion of the rule of law towards the Western Balkans, and its development with the main challenges and shortcomings. Finally, the paper analyses the EU accession process of North Macedonia as a case study.

\section{EU enlargement as a process of Europeanisation: rule of law conditionality with regard to the fifth (and sixth) EU enlargement in 2004 and 2007}

This section elaborates on the conditionality policy employed towards Central and Eastern European countries (CEECs) with regard to the rule of law and the internalisation of the reforms in the post-accession context. This is needed in order to move forward with the role of the rule of law in the accession process of the Western Balkan states.

The first generation of accessions to the EU was based on political decisions without any clear criteria having been established, only providing for basic rules, namely Article 237 EEC - to be European and to be willing to take part. No specific policy had been developed, only enlargement rules which can be characterised as non-interventionist in terms of EU engagement with the candidates' preparation for accession and fulfilment of the entry conditions. ${ }^{13}$ The political acknowledgment by the 1993 Copenhagen European Council ${ }^{14}$ on the European future of post-communist Central and Eastern European countries was accompanied by certain membership criteria that mark the emergence of the EU enlargement policy. In addition to the applicants' acceptance of the EU acquis, including for the first time the CFSP and JHA acquis, the candidates would have to fulfil the so-called 'Copenhagen criteria'. Moreover, it initiated the development of EU Member States' comprehensive role in the process, as it stated that 'the European Council will continue to follow closely progress in each associated country towards fulfilling the conditions of accession to the Union and draw the appropriate conclusions.'. ${ }^{15}$

This further articulated the 'pre-accession strategy'16 which turned enlargement into a policy with a transformative aim, thereby introducing the EU into a normative power in Europe. ${ }^{17}$ Given that the Copenhagen

\footnotetext{
${ }^{13}$ Christophe Hillion, 'EU Enlargement' in Paul Craig and Grainne de Búrca (eds), The Evolution of EU Law (2 $2^{\text {nd }}$ edn, OUP 2018).

${ }^{14}$ European Council, Presidency Conclusions, Copenhagen, 21-22 June 1993.

15 ibid.

${ }^{16}$ European Council, 'Presidency Conclusions', Madrid, 15-16 December 1994.

17 Hillion (n 13) 196.
} 
criteria were expressed by the European Council as 'obligations of membership', they have to be read jointly with the relevant Treaty provisions which in 1993 were to be found in Article O of the Treaty on European Union (TEU) signed in Maastricht - 'the conditions of admission and the adjustments to the Treaties on which the Union is founded which such admission entails shall be the subject of an agreement between the Member States and the applicant State'. The political condition that the accession process has to be linked to the rule of law became part of primary law and thus legally binding under the Amsterdam Treaty in 1999 which enshrined the constitutional principles, later further reinforced with the Lisbon Treaty speaking of values.

\subsection{The rule of law 'enlargement acquis'}

In regard to the CEECs, the European Commission defined its political criteria in Agenda 2000 as a combination of free and fair elections, political pluralism, freedom of expression and freedom of religion, the need for democratic institutions, and independent judicial and constitutional authorities. ${ }^{18}$ One of the main reasons for the inclusion of the rule of law as a requirement for membership was because it was considered important and necessary for the formation and support of an 'autonomous civil and political society' in transition countries, especially those which were formerly governed by an authoritarian government. ${ }^{19}$ On the basis of the Copenhagen political criteria, when it assessed the applications for accession, the Commission undertook a review of the current situation which went beyond a formal description of political institutions and covered the ability of the country's administrative and judicial systems as an element of the rule of law. All the applicant countries had flaws in the rule of law, where it was stated that there was a lack of suitably qualified judges and guarantees of their independence, and police forces were poorly paid and required better training and discipline. ${ }^{20}$

Literature on European integration produced the term 'Europeanisation' to explain the process of 'downloading' EU legislation and policy into the national polity, and sometimes also the 'uploading' of national preferences to the EU level. ${ }^{21}$ In contrast to the Member States' two-way

${ }_{18}$ Commission, 'Agenda 2000 - Volume I - Communication: For a Stronger and Wider Union' DOC/97/6, 15 July 1997.

${ }^{19}$ Juan Linz and Alfred Stepan, 'Toward Consolidated Democracies'(1996) 7(2) Journal of Democracy 14, 18.

${ }^{20}$ European Parliament, 'Briefing No 20 Democracy and respect for human rights in the enlargement process of the European Union', Brussels, 1 April 1998 <www.europarl.europa. eu/enlargement/briefings/20a2_en.htm\#top> accessed 12 June 2021.

${ }^{21}$ Tanja A Börzel, 'Institutional Adaptation to Europeanization in Germany and Spain' (1999) 37(4) Journal of Common Market Studies 573. 
street, Europeanisation in the accession process narrowed to a one-way street for downloading EU policies. ${ }^{22}$ The most encompassing definition of this concept describes it as

processes of (a) construction, (b) diffusion, and (c) institutionalization of formal and informal rules, procedures, policy paradigms, styles, 'ways of doing things' and shared beliefs and norms which are first defined and consolidated in the making of EU decisions and then incorporated in the logic of domestic discourse, identities, political structures, and public policies. ${ }^{23}$

A large body of Europeanisation literature ${ }^{24}$ claims that the EU has been transforming and democratising power and that it brought the rule of law to candidate countries. The influence of an enlarging EU has created convergence towards liberal democracy throughout the region and the EU's active leverage has inspired modernisation of the judiciary as one area where 'many governments were only galvanized into action by the full use of the EU's conditionality'. ${ }^{25}$ Hence, EU pressure for reform had an impact on the governance of the judicial branch and the governance of the courts, but the absence of a clear institutional model by the EU brought divergent outcomes of judicial reform across these countries. ${ }^{26}$ Other 'rule of law' areas of particular interest were human and minority rights, and the Europeanisation process led to the adoption of minority rights and anti-discrimination legislation through the particular choice of rules within the scope of the EU's conditionality. ${ }^{27}$

Although the rule of law was included in the Copenhagen criteria and the Amsterdam principles, the approach in this enlargement focused mainly on the legal transposition of the EU acquis and institution building - the necessary administrative and judicial structures for the correct application of EU legislation, whereby the rule of law was not touched upon in its substance. Due to the limited scope of the EU acquis in many of these areas covered by the Copenhagen criteria, mainly the

\footnotetext{
${ }^{22}$ Frank Schimmelfennig and Ulrich Sedelmeier, 'The Europeanization of Eastern Europe: The External Incentives Model' (JMF@25 conference, EUI, 22-23 June 2017).

${ }^{23}$ Claudio Radaelli, 'The Europeanization of Public Policy' in Kevin Featherstone and Claudio Radaelli (eds), The Politics of Europeanization (OUP 2003).

${ }^{24}$ For an overview, see Ulrich Sedelmeier, 'Europeanisation in New Member and Candidate States' (2011) 6(1) Living Reviews in European Governance 5.

${ }^{25}$ Milada A Vachudova, Europe Undivided: Democracy, Leverage, and Integration after Communism (OUP 2005) 187.

${ }^{26}$ Daniela Piana, 'The Power Knocks at the Courts' Back Door: Two Waves of Postcommunist Judicial Reforms' (2009) 42(6) Comparative Political Studies 816.

${ }^{27}$ Guido Schwellnus, The Adoption of Nondiscrimination and Minority Protection Rules in Romania, Hungary, and Poland' in Ulrich Schimmelfennig and Frank Sedelmeier (eds), The Europeanization of Central and Eastern Europe (Cornell University Press, 2005).
} 
rule of law, the missing normative content was filled by referring to the European standards developed by other regional/international organisations such as the Council of Europe rules or OSCE principles. More importantly, at least in the short term, these organisations and their rules and principles have become "powerful standard setters and providers of information' ${ }^{28}$ for the EU's pre-accession process. In the light of the EU accession process, candidate countries were admitted by the Council of Europe whose membership expanded from twenty-three states in 1989 to forty in 1999, and accepted the obligations towards these regional/international organisations as requirements for EU membership. The main elements of the EU-driven reforms referred to the intensified alignment of domestic legislation with European and international standards, including approximation with the acquis communautaire, as well as increased legislative output that potentially weakened legal stability. ${ }^{29}$

Even so, this approach brought difficulties on how to measure progress and was criticised for its rather 'simplistic sum' ${ }^{30}$ of the rule of law and democracy and the lack of 'actual substance'. ${ }^{31}$ In this manner, there was a discrepancy between the accession conditions and membership obligations because the norms the Union has promoted in the context of enlargement go well beyond the perimeter of the EU acquis stricto sen$s u .^{32}$ Lack of a uniform conception of the rule of law affected how applicant countries reform their governmental structures according to their interpretation of the concept and has the potential of influencing and disrupting the further expansion of the EU to include countries from Central and Eastern Europe. ${ }^{33}$ Another significant issue that needs to be pointed out is that there is the possibility that the lack of a formalised uniform conception of the rule of law means that assessment of an applicant country's transformation may be unfair and illegitimate. Therefore, the rule of law is part of the so-called 'enlargement acquis' within the EU's accession conditionality but not, or only to a limited extent, part of the EU acquis. ${ }^{34}$

\footnotetext{
28 Vachudova (n 25) 134.

${ }^{29}$ Martin Mendelski, The EU's Rule of Law Promotion in Central and Eastern Europe: Where and Why Does It Fail, and What Can be Done About It? (Bingham Centre for the Rule of Law 2016) 5.

${ }^{30}$ Allan Tatham, Enlargement of the European Union (Kluwer Law International 2009) 209.

${ }^{31}$ Päivi Leino, 'Rights, Rules and Democracy in the EU Enlargement Process: Between Universalism and Identity' (2002) 7 Austrian Review of International and European Law 53, 80. ${ }^{32}$ Hillion (n 13) 196.

${ }^{33}$ Dale Mineshima, 'The Rule of Law and the Eastern Enlargement of the EU' (PhD thesis, Old Elvet Durham University 2001) 109 <http://etheses.dur.ac.uk/3827/> accessed 5 June 2021.

${ }^{34}$ Tomasz P Woźniakowski, Frank Schimmelfennig and Michal Matlak, 'Europeanization Revisited: An Introduction' in Tomasz P Woźniakowski, Frank Schimmelfennig and Michal Mat-
} 


\subsection{Post-accession rule of law interaction}

It must be noted that the rule of law reforms in substance require embedding the European standards and implementing the adopted laws, and thus it is important not to prejudice the effects of the accession process and how deeply these reforms have penetrated into the applicants' institutions in terms of long-term developments. The accession process has been mostly about harmonisation of legal rules with no clear vision of the actual meaning of these rules and transformation on the ground that should come with it, so the adjustment remained for the future, pointing to the difference between formal rule adoption and genuine internalisation of EU values and standards. ${ }^{35}$ Post-accession experience showed that in these areas the EU often gave "priority to efficiency over legitimacy ${ }^{36}$ regardless of the conditionality policy, which meant that candidate countries were required to adapt their laws and institutions significantly before any date of accession was set.

Chart 1. Rule of law in the CEE candidate countries 1996-2020

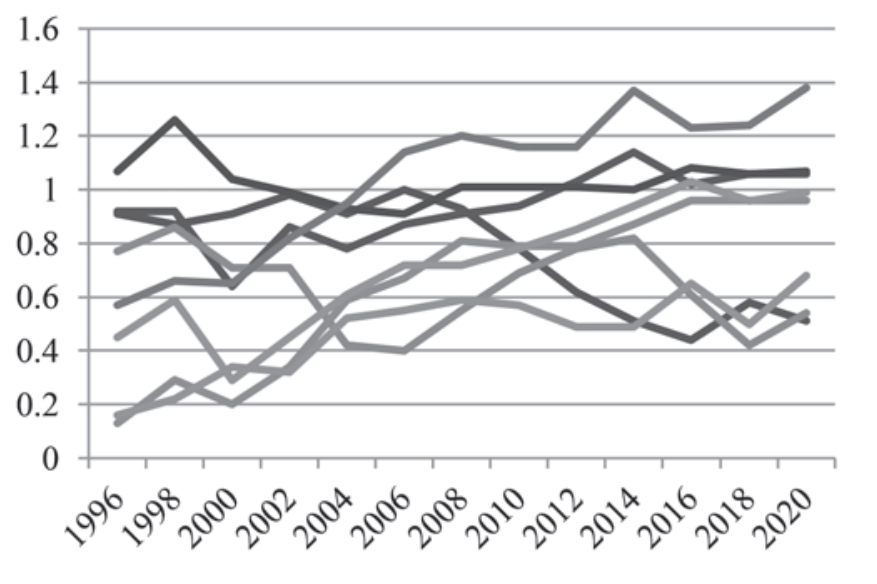

Czech Republic

- Hungary

Poland

Slovenia

Estonia

Latvia

Lithuania

- Slovakia

Source: Author's calculations based on World Bank's Worldwide Governance Indicators

lak (eds), Europeanization Revisited: Central and Eastern Europe in the European Union (European University Institute and Robert Schuman Centre for Advanced Studies, 2018) 6, 11.

${ }^{35} \mathrm{~S}$ Rodin, 'Discourse and Authority in European and Post-Communist Legal Culture' (2005) 1 Croatian Yearbook of European Law and Policy 1, 15.

${ }^{36}$ Heather Grabbe, The EU's Transformative Power. Europeanization through Conditionality in Central and Eastern Europe (Palgrave Macmillan 2006) 205. 
Chart 2. Rule of law in the (enlarged) EU 1996-2020

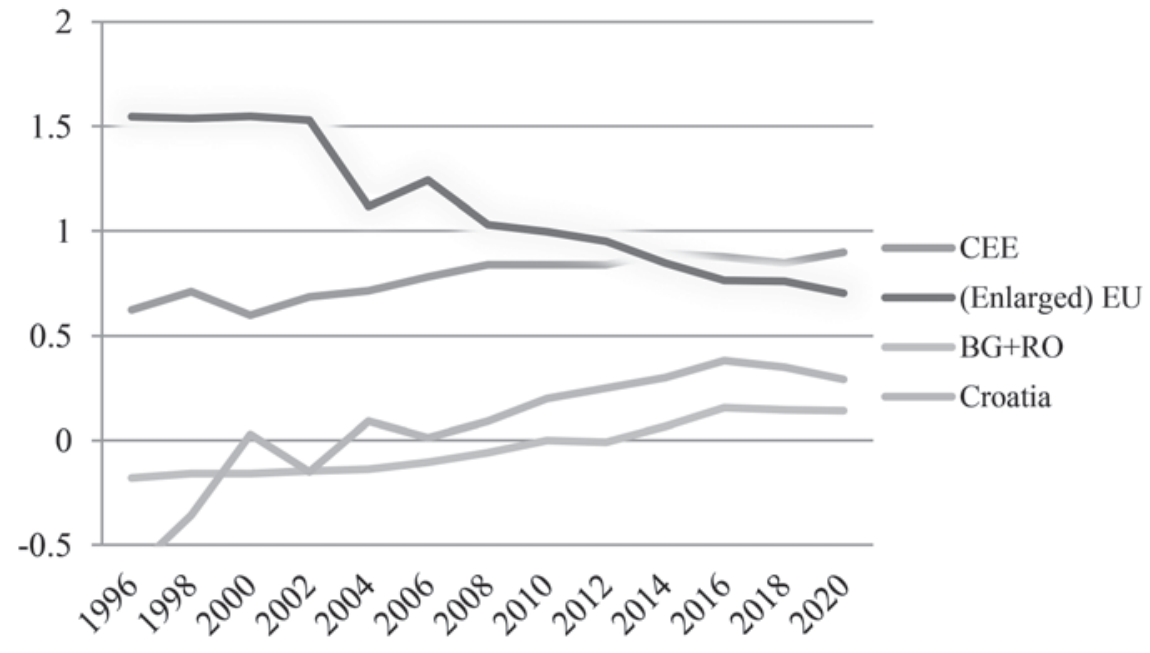

Source: Author's calculations based on World Bank's Worldwide Governance Indicators

These figures suggest that at the time CEE countries became official members of the European Union in 2004, they had not yet met the European standards with regard to the rule of law, ie their index was lower than the EU average that had also decreased at that time. Moreover, it became apparent that the Europeanisation process may even be reversible - post-accession experience revealed stagnating and even declining trends, where the rule of law had not improved significantly and had even further deteriorated, ${ }^{37}$ thus questioning the EU transformative pow-

\footnotetext{
${ }^{37}$ In addition to the presented figures, in its 2021 Rule of Law Report as a comprehensive assessment of developments affecting the rule of law across EU Member States, the European Commission expressed concerns with regard to Poland and Hungary, where the situation has only further deteriorated. Several mechanisms for upholding the rule of law have been already activated, including launching infringement procedures. See Commission, Communication from the Commission to the European Parliament, the Council, the European Economic and Social Committee and the Committee of the Regions COM(2021) 700. The situation culminated with Judgment $\mathrm{K} \mathrm{3/21}$ of the Constitutional Tribunal of Poland - Assessment of the conformity to the Polish Constitution of selected provisions of the Treaty on European Union from 7 October 2021, which declared Articles 1, 2 and 19 of the Treaty on European Union (TEU) to be partially unconstitutional. Article 19 TEU gives concrete expression to the value of the rule of law set out in Article 2 TEU and requires Member States to provide effective judicial protection in the fields covered by Union law. This ruling opposes the jurisdiction of the CJEU and the principle of EU law supremacy which is inherent to the rule of law. Therefore, EC President von der Leyen in her speech at the European Parliament Plenary held on 19 October 2021 addressed this situation as 'rule of law crisis' <https://ec.europa.eu/commission/presscorner/detail/en/speech_21_5361> accessed 22 November 2021.
} 
er in the frame of the conditionality policy based on the 'stick and carrot' model. Even so, the EU introduced certain instruments of post-accession conditionality in the form of safeguard clauses to address 'serious shortcomings or any imminent risks of such shortcomings in transposition, state of implementation or the application of framework decisions or any other relevant commitments, instruments of co-operation and decisions' with regard to Justice and Home Affairs. ${ }^{38}$ Such measures could have been adopted during the first three years after accession but they were never activated which further undermined the EU post-accession conditionality. On the other hand, some of the countries which were perceived as laggards, such as the Baltic states, have become role models of EU transformative power, thus emphasising that the Europeanisation process does not end with the accession date and includes also 'member-state building. ${ }^{39}$

\subsection{The last 'big bang' enlargement spark}

Although Bulgaria and Romania were "part of the same inclusive and irreversible enlargement process', ${ }^{40}$ these countries were not among the states which were included in the 'big bang' enlargement in 2004 and their accession process differed in some respects from that of the CEE countries. The actual capacity to fulfil the Copenhagen criteria along with the domestic salience of accession allowed the EU to add specific requirements to the general criteria for opening negotiations, suggesting that EU conditionality was toughening for new waves of applicants. ${ }^{41}$ However, in order for the EU to verify its transformative power and achieve the desired reforms in Bulgaria and Romania, it had to maintain the long-term membership promise as the uncertainty over prospects for membership was a major difficulty in the course of internal reforms. ${ }^{42}$

\footnotetext{
${ }^{38}$ Article 39 of the Treaty between the Member States of the European Union and the Czech Republic, the Republic of Estonia, the Republic of Cyprus, the Republic of Latvia, the Republic of Lithuania, the Republic of Hungary, the Republic of Malta, the Republic of Poland, the Republic of Slovenia, the Slovak Republic, concerning the accession of the Czech Republic, the Republic of Estonia, the Republic of Cyprus, the Republic of Latvia, the Republic of Lithuania, the Republic of Hungary, the Republic of Malta, the Republic of Poland, the Republic of Slovenia and the Slovak Republic to the European Union [2003] OJ L236/17.

${ }^{39}$ See Andriy Tyushka, 'Twists and Turns of Democratic Transition and Europeanisation in East-Central Europe Since 1989: Betwixt EU Member and Neighbour State-Building’ (2020) 16 Croatian Yearbook of European Law and Policy 133.

${ }^{40}$ Council of the European Union, 'Presidency Conclusions', Brussels, 19-20 June 2003.

${ }^{41}$ Pavlina Nikolova, 'Negotiating for EU Membership? The Case of Bulgaria and Romania' (2006) 2 Croatian Yearbook of European Law and Policy 393, 400.
}

42 ibid. 
These two countries signed the Accession Treaty in $2005^{43}$ which introduced a 'super safeguard' clause (Article 39) allowing the EU to postpone the accession, together with the 'standard' safeguard clause (Article 38) with the possibility of it being invoked even before accession and enhanced monitoring by which the Commission preserved the right to monitor Bulgaria's and Romania's judicial systems and the fight against corruption and organised crime. The super-safeguard clause had arguably become one of the mainstays of the EU enlargement policy, allowing the EU to give an irreversible political promise of membership, but to take time to ensure that the requirements are met in full before the actual date of accession. ${ }^{44}$ Furthermore, the Act of Accession in relation to Article 39 contains an Annex (Annex IX) on the specific commitments undertaken and requirements accepted by Romania at the conclusion of the accession negotiations whereby most of them correspond with specific measures on the fight against corruption (against high-level corruption in particular) and judiciary reforms. The rule of law was written all over these post-accession conditionality instruments that confirmed the 'evolutionary nature of EU conditionality' and its new feature, that of post-accession conditionality. ${ }^{45}$

However, both countries were allowed to accede to the EU on the pre-scheduled date of 1 January 2007 but the new instruments invented to deal with (un)foreseen developments during the first years of accession suggested greater concern on the EU side with implementation capacity and progress on the ground. In order for the EU not to lose leverage when the two countries obtained official membership, Bulgaria and Romania remained under the Commission's continuous scrutiny after the accession date within the Cooperation and Verification Mechanism (CVM) ${ }^{46}$ which defined benchmarks for the fight against corruption, organised crime and the reform of the judiciary against which their progress was

\footnotetext{
${ }^{43}$ Treaty between the Member States of the European Union and the Republic of Bulgaria and Romania, concerning the accession of the Republic of Bulgaria and Romania to the European Union [2005] OJ L157/11.

${ }^{44}$ Nikolova (n 41) 411.

${ }^{45}$ Eli Gateva, 'Post-Accession Conditionality Support Instrument for Continuous Pressure?'(2010) 18 KFG Working Paper Series 1.

${ }^{46}$ Commission Decision of 13 December 2006 establishing a mechanism for cooperation and verification of progress in Bulgaria to address specific benchmarks in the areas of judicial reform and the fight against corruption and organised crime, C(2006) 6570, Brussels.

Commission Decision of 13 December 2006 establishing a mechanism for cooperation and verification of progress in Romania to address specific benchmarks in the areas of judicial reform and the fight against corruption, C(2006) 6569, Brussels.
} 
to be measured, and thus gained much of the EU focus and the attention of public debate. ${ }^{47}$

The safeguard clause on JHA and the CVM were interconnected since the establishment of the CVM further specifies that if Bulgaria and/or Romania 'fail to address the benchmarks adequately, the Commission may apply safeguard measures based on Articles $37^{48}$ and 38 of the Act of Accession'. Contrary to the monitoring findings, ${ }^{49}$ the Commission however neither invoked any of the sanctions included in the safeguard provisions nor established new sanctions in the framework of the CVM. Nevertheless, although formal compliance with EU law has not decreased since their accession, signs of shortcomings in the rule of law areas have appeared possibly on a greater scale than in other CEE countries, ${ }^{50}$ as can be seen from the data presented in Table 2. In order to address Bulgaria's and Romania's post-accession compliance record, it is important to distinguish between compliance with EU legislation in terms of transposition, implementation and enforcement of EU law (general compliance) and compliance with the CVM benchmarks (or CVM compliance) which cover particular policy areas, namely the fight against organised crime and corruption and the efficiency of the judicial system. Although both types of compliance are interlinked (the effectiveness of the judiciary inevitably affects the implementation and enforcement of EU law), general compliance and CVM compliance operated within different frameworks, ${ }^{51}$ having in mind that the specific areas covered under CVM lacked original content within the EU acquis. It must be noted that this new element of the accession process did not yield the same results in both countries - Romania performed better than Bulgaria. From this point of view, the two countries can be considered as being 'either the last to benefit from the old enlargement policies or the first to experience the novel, and expectedly more restrictive stance of the EU to the admission of new member states'. ${ }^{52}$ The post-accession conditionality instruments established with regard to Bulgaria and Romania did

\footnotetext{
${ }_{47}$ Neculai-Cristian Surubaru and Cristian Nitoiu, 'One Decade Onwards: Assessing the Impact of European Union Membership on Bulgaria and Romania' 2021 (22)2 European Politics and Society 161.

${ }^{48}$ Internal market safeguard clause.

${ }^{49}$ Commission, Report from the Commission to the European Parliament and the Council on Progress in Bulgaria under the Co-operation and Verification Mechanism COM (2010) 400.

Commission, Report from the Commission to the European Parliament and the Council on Progress in Romania under the Co-operation and Verification Mechanism COM (2010) 401.

50 Trauner (n 6) 2-5.

${ }^{51}$ Gateva (n 45) 6.

${ }^{52}$ Daniel Smilov, 'Enlargement and EU Constitutionalism in the Balkan Periphery' in Wojciech Sadurski, Jacques Ziller and Karolina Zurek (eds), Après Enlargement: Legal and Political Responses in Central and Eastern Europe (EUI - Robert Schuman Centre 2006) 161.
} 
not provide strong incentives for compliance with EU conditions at this stage and have become a credibility issue for the EU and an argument against further enlargement ${ }^{53}$ with an enhanced focus on pre-accession.

\subsection{Patching the gaps}

The decision to allow the accession of 'imperfect' new Member States did not follow consistently the ratio behind the conditionality policy but represented primarily a political decision driven by 'wider security imperatives' to some extent. ${ }^{54}$ Hence, the identified problems and inconsistencies pointed to 'the gap between conditionality on paper and conditionality in practice', ${ }^{55}$ suggesting that 'conditionality can only become a true principle of enlargement, when the whole accession process is mostly moved away from the sphere of politics into the realm of the law'. ${ }^{56}$ This situation impacted the internal dimension of the rule of law within the European Union as well (see Chart 2). If the driving force behind the Treaty of Nice in 2004 was to make the necessary institutional changes for further enlargement, ${ }^{57}$ then the Amsterdam Treaty shyly introduced mechanisms for protecting the rule of law within the European Union which were further translated into the Lisbon Treaty.

Article 7 TEU establishes a procedure to sanction a Member State which does not uphold EU values, including the rule of law, through the suspension of membership rights. Furthermore, confronted with crisis events in Hungary and Poland which revealed systemic threats to the rule of law, the Commission in 2014 set the Rule of Law Framework ${ }^{58}$ to prevent the emergence of a systemic threat to the rule of law, at which point an Article 7 TEU procedure would be required. The EU rule of law repressive toolbox, consisting of a pre-Article 7 and Article 7 TEU procedure together with the infringement procedure which is to be opened by the Commission when a Member State violates or fails to apply Union law, has been applied against Hungary and Poland ${ }^{59}$ in order to bring both countries back into the European fold of the rule of law.

\footnotetext{
${ }^{53}$ Gateva (n 45) 20-21.

${ }^{54}$ Dimitris Papadimitriou and Eli Gateva, 'Between Enlargement-led Europeanisation and Balkan Exceptionalism: An Appraisal of Bulgaria's and Romania's Entry into the European Union' (2009) 10(2) Perspectives on European Politics and Society 152, 164.

55 Dimtiry Kochenov, EU Enlargement and the Failure of Conditionality: Pre-accession Conditionality in the Fields of Democracy and the Rule of Law (Kluwer Law International 2008) 311.

56 ibid, 312.

57 Paul Craig, and Grainne de Búrca (eds), EU Law: Text, Cases and Materials (OUP 2011) 21.

${ }^{58}$ Commission, 'A New EU Framework to Strengthen the Rule of Law' (Communication) $\operatorname{COM}(2014) 158$.

59 The Commission has used the Rule of Law Framework only once, to try to stop certain developments in Poland. The procedure to invoke a clear risk of a serious breach under
} 
More recently, it was announced ${ }^{60}$ that the European Commission had sent a letter to both countries requesting certain information as the first (informal) step towards triggering the latest mechanism ${ }^{61}$ which allows for the reduction or suspension of EU funds to Member States due to breaches of the principles of the rule of law, in particular those that affect the proper functioning of public authorities and effective judicial review that can seriously harm the financial interests of the Union. Prior to this, the European Parliament had submitted a lawsuit to the Court of Justice against the European Commission for its failure to apply this mechanism. ${ }^{62}$ The need to further introduce and activate various rule of law internal mechanisms implies that the EU has not been effective in addressing the situation in these countries which is only deteriorating.

\section{Prioritising the rule of law as an accession criterion: a common challenge for the EU and the Western Balkans}

The EU has developed a normative basis against which new admissions would be assessed and in the framework of which the enlargement policy will be conducted, so these new rules have since become applicable in the accession process of the candidate countries from the Western Balkans (WB). ${ }^{63}$ In its 1997 Conclusions, ${ }^{64}$ the Council declared the political criteria that South East European (SEE) countries (including WB countries) need to fulfil to establish contractual relations with

Article 7(1) TEU has been triggered in two cases so far: in December 2017, by the Commission in respect of Poland, and in September 2018, by the European Parliament in respect of Hungary. The first infringement case brought to the CJEU on a rule of law issue was Case 286/12-Compulsory retirement of judges, regarding the lowering of the retirement age of Hungarian judges and other legal professionals. In terms of Poland, the Commission launched several infringement procedures on rule of law issues concerning the implementation of judicial reforms: early retirement of ordinary judges (Case 192/18, Judgment of 5 November 2019); early retirement of Supreme Court judges (Case 619/18, Judgment of 24 June 2019); a new disciplinary regime for judges (Case 791/19, 15 July 2021); as well as the newest infringement procedure regarding the new law on the judiciary of 20 December 2019, which entered into force on 14 February 2020.

60 Zosia Wanat and Lili Bayer, 'Brussels Takes Step toward Rule-of-law penalty Process with Poland, Hungary' Politico (19 November 2021) <www.politico.eu/article/eu-rule-oflaw-penalty-process-poland-hungary/> accessed 24 November 2021.

61 Regulation 2020/2092 of the European Parliament and of the Council of 16 December 2020 on a general regime of conditionality for the protection of the Union budget [2021] OJ L433/ 1 .

${ }^{62}$ European Parliament, 'Parliament Files Lawsuit against Commission over Rule of Law Mechanism', Brussels, 29 October $2021<$ https://the-president.europarl.europa.eu/en/ newsroom/parliament-files-lawsuit-against-commission-over-rule-of-law-mechanism> accessed 24 November 2021.

${ }^{63}$ Hillion (n 13) 193.

${ }^{64}$ Council of the European Union, 'General Affairs Council Conclusions', Luxembourg, 2930 April 1997. 
the EU and made reference to the rule of law. ${ }^{65}$ These conclusions clarify the standards for the verification of compliance with the accession criteria, and, with respect to the rule of law, they identify the following elements: freedom of expression, including independent media, the right of assembly and demonstration, the right of association, the right to privacy, the right to property, effective means of redress against administrative decisions, access to courts and the right to a fair trial, equality before the law and equal protection by the law, freedom from inhuman or degrading treatment, and arbitrary arrest.

The EU's political strategy for the Western Balkans ${ }^{66}$ with regard to the European perspective inaugurated by the Zagreb Summit in 2000 is being implemented in the framework of the Stabilisation and Association Process that combines the creation of privileged political and economic relations supported by financial assistance. Stabilisation and Association Agreements contain specific conditionality clauses according to which respect for the rule of law constitutes an essential element of these agreements with the possibility of taking appropriate measures, even the suspension of the application of the agreement, in the case of non-compliance. The rule of law is evoked not only in the conditionality clauses, but also in other provisions concerning cooperation on justice, freedom, and security, whereby consolidation of the rule of law is closely linked to the strengthening of institutions, in particular the executive and the judiciary. ${ }^{67}$ In the following subsection, the paper focuses on how the EU enlargement policy and approach to accession negotiations with the Western Balkans has developed over time in order to identify the main phases and how they differ from one another.

\subsection{Introduction and rise of Chapter 23}

\footnotetext{
${ }_{65}$ Ivan Damjanovski and Marko Kmezić, 'Europeanisation and Institutionalisation of EU Rules in the Western Balkans' in Eric Gordy and Adnan Efendic (eds), Meaningful Reform in the Western Balkans: Between Formal Institutions and Informal Practices (Peter Lang 2019) 20,28 .

${ }^{66}$ The term 'Western Balkans' has a geopolitical character. It was first used at the beginning of the 1990s to denote the former Yugoslav republics (but not Slovenia) and Albania. In the context of EU integration, the denomination was introduced in 1996/1997 when the respective regional approach was established. By applying the term 'Western Balkans', the EU introduced a distinction between the Western Balkans and Central and East European (CEE) countries, which actually include the Western Balkan countries. That distinction is also reflected in the EU accession process of the latter.

${ }^{67}$ Lara Appicciafuoco, 'The Promotion of the Rule of Law in the Western Balkans: The European Union's Role' (2010) 11(8) German Law Journal 741, 763.
}

For example, see SAA FYROM, Art 74; SAA Croatia, Art 75; SAA Albania, Art 78; SAA Montenegro, Art 80; SAA Serbia, Art 80; SAA BiH, Art 78. 
The experience from the enlargement negotiations with CEE countries, especially Bulgaria and Romania, had a significant impact on the development of the accession process. As the enlargement has proved so far, all the assistance, conditionality, and benchmarking, combined with the political promise of full membership, are not strong enough to serve as catalysts for deep and comprehensive reforms. ${ }^{68}$ With the Enlargement Strategy 2005, the Commission introduced a reinforced monitoring system with regard to the rule of law into the Western Balkan countries' accession process. ${ }^{69}$ According to the 2006 European Council conclusions, the updated consensus on the enlargement policy enhanced the importance of the rule of law: 'accordingly, difficult issues such as administrative and judicial reforms and the fight against corruption will be addressed at an early stage. ${ }^{70}$ If the approach employed towards the CEE countries focused mainly on 'institution building, ${ }^{71}$ in the case of Bulgaria and Romania and from Croatia onwards the accession process was based on the rule of law, including the fight against corruption. This approach was also reflected within the Treaty of Lisbon (Article 49 TEU) that introduced the commitment to respect the rule of law as a condition for EU membership. Hence, apart from standing as a pillar of EU identity, this principle is now operationally used as an eligibility criterion for EU membership..$^{72}$ The concept of the rule of law in the EU enlargement process $^{73}$ is covered by the newly introduced Chapter 23 - Judiciary and Fundamental Rights (first met in the Croatian negotiating process) and Chapter 24 - Justice, Freedom and Security of the EU acquis which are central in the Europeanisation process, and the overall progress of the EU acceding country is based on these criteria. Therefore, the EU requires the Western Balkan countries to demonstrate a credible track record of a properly functioning judicial system, the effective fight against corruption, and protection of fundamental rights.

Based on the lessons learned, the EU assumed a more rigorous position in the negotiations with Croatia with regard to (closing) Chapter 23 and Chapter 24 and put forward a new accession approach consisting

\footnotetext{
${ }^{68}$ Adam Lazowski, 'European Union Do Not Worry, Croatia Is Behind You: A Commentary on the Seventh Accession Treaty' (2012) 8 Croatian Yearbook of European Law and Policy 1,34 .

${ }^{69}$ Commission (n 8).

${ }^{70}$ European Council, 'Presidency Conclusions', Brussels, 15 December 2006.

${ }^{71}$ Nedim Hogić, 'The European Union's Rule of Law Promotion in the Western Balkans: Building a Rule of Law Constituency' (2020) 16 Croatian Yearbook of European Law and Policy 197, 201.

${ }^{72}$ Amichai Magen, 'Cracks in the Foundations: Understanding the Great Rule of Law Debate in the EU' (2016) 54(5) Journal of Common Market Studies 1050.

${ }^{73}$ According to the EU's Enlargement Strategy 2011/2012 developed by the European Commission which lists the areas included in the rule of law concept.
} 
of much stricter conditionality and benchmarking, particularly in the areas of the judiciary and fundamental rights. As stated in the Negotiating Framework ${ }^{74}$ the pace of accession negotiations is determined by the fulfilment of the conditions on the rule of law, which are those scheduled by the Copenhagen criteria, as well as those laid down in the framework of the SAP, and in particular in the relevant SAA. Moreover, in the event of a serious and persistent breach by Croatia of the principles of liberty, democracy, human rights and fundamental freedoms, and the rule of law, the Commission could have recommended suspension of negotiations and proposed conditions for their resumption. Although Chapter 23 was the main novelty regarding the rule of law in the case of Croatia, it did not gain a central role at the beginning of the accession negotiations in 2005. This Chapter was eventually opened among the last ones in the negotiations in June 2010 by setting three opening benchmarks or one for each of the areas - the judiciary, anti-corruption and fundamental rights. These benchmarks were related to the adoption or revision of national strategies and action plans regarding the judiciary and anti-corruption, as well as two separate plans for the implementation of the already existing constitutional act on the rights of national minorities and particular programmes in the last area, that is, fundamental rights. However, in the last stages of the accession negotiations, the EU imposed ten closing benchmarks for this Chapter, with difficult sub-benchmarks both in quantity (number of) and in quality (content-wise). Most of the closing benchmarks required actual progress on the ground expressed through the term 'track record', but, as this notion implies, it takes time for tangible results of the undertaken reforms. ${ }^{75}$

Taking pre-accession control beyond the borders of enlargement policy, the Treaty concerning the accession of Croatia to the $\mathrm{EU}^{76}$ contained 'specific commitments undertaken by the Republic of Croatia in the accession negotiations', which refer to the commitment to strengthen the independence, responsibility, impartiality and professionalism of the judiciary and to foster the protection of human rights. Article 36 of the Accession Treaty signed in December 2011 contains a special monitoring mechanism that became applicable on the date of its signature, which means even before the accession. This mechanism was operationalised through monitoring reports prepared by the Commission - one named

\footnotetext{
${ }^{74}$ Negotiating Framework, 3 October $2005<$ http://ec.europa.eu/enlargement/pdf/croatia/ st20004_05_hr_framedoc_en.pdf> accessed 27 June 2021.

75 See Mirna V Feketija and Adam Lazowski, 'The Seventh EU Enlargement and beyond: Pre-Accession Policy Vis-à-Vis the Western Balkans Revisited' (2014) 10 Croatian Yearbook of European Law and Policy 1, 17.

${ }^{76}$ Treaty between Member States of the European Union and the Republic of Croatia concerning the accession of the Republic of Croatia to the European Union [2021] OJ L112/10.
} 
State of Preparedness for EU membership in April $2012^{77}$ based on the 2011 Enlargement Package, and the Comprehensive Monitoring Report in October 2012, ${ }^{78}$ while Croatia responded with an Action Plan that was revised on the basis of the second report's recommendations. Nevertheless, the introduction of this mechanism indicates that the rule of law criteria were not fulfilled at the time when the negotiations were concluded and a list of actions to be taken was still pending before the accession date scheduled by the Accession Treaty for 1 July 2013.

\subsection{The new approach as a 'key' innovation}

Further requirements were gradually introduced by the European Commission on the basis of the Enlargement Strategies and elaborated in the (Progress) Reports for each country where comparison of these reports reveals a more significant role of the rule of law areas with regard to the Western Balkan countries versus the CEE countries that joined in 2004. The 'new approach in the enlargement process' concerning the prioritisation of the rule of law reforms in candidate countries was officially introduced with the Enlargement Strategy in $2011 .{ }^{79}$ It relies on the principle that issues relating to the judiciary and fundamental rights as well as justice, freedom, and security 'should be tackled early in the accession process and the corresponding chapters opened accordingly on the basis of action plans, as they require the establishment of convincing track records'. ${ }^{80}$ Moreover, measuring the success or failure in fulfilling the principle of the rule of law is based on set benchmarks, including opening and closing but also interim benchmarks that would assess the country's progress in the negotiating chapter, where the overall progress in Chapters 23 and 24 determines the pace and dynamics of the negotiations as a whole (overall balance clause). Therefore, the Western Balkan countries are expected to get a head start on the rule of law reforms as the most difficult aspect in order to allow enough time to build solid track records of implementation before opening other negotiating chapters.

This new approach was first applied with regard to the negotiations with Montenegro and then consequently in the negotiations with Serbia, as it was intended to further strengthen the accession process by avoiding the need for post-accession instruments. The European Council

\footnotetext{
${ }_{77}$ Commission, 'Monitoring Report on Croatia's accession preparations' (Communication) COM (2012) 186.

${ }^{78}$ Commission, 'Main Findings of the Comprehensive Monitoring Report on Croatia's State of Preparedness for EU Membership' (Communication) COM (2012) 601 final.

${ }^{79}$ Commission, 'Enlargement Strategy and Main Challenges 2011-2012' (Communication) $\operatorname{COM}(2011) 666$.

80 ibid 5.
} 
stated that the accession negotiations with Montenegro would be led according to the 'renewed enlargement consensus' emphasised in the 2006 Conclusions, established practice, but also according to the 'new approach' with regard to Chapters 23 and $24 .{ }^{81}$ The Commission prepared a report ${ }^{82}$ on the additional progress by Montenegro since 1 September 2011 on implementation of the reforms in the key priority areas, with special focus on the judiciary, fundamental rights, and the fight against corruption and organised crime on the basis of which the official date for opening the accession negotiations was set. ${ }^{83}$ The negotiation framework for Montenegro envisages Chapters 23 and 24 as key chapters that are first to be opened and last to be closed, also introducing a modification to the suspension clause in order to provide balanced progress during the negotiations on the individual chapters. Hence, the Commission would be authorised, on its own initiative or by the request of one-third of the Member States, to withdraw the recommendation to open or close any other chapter as long as the backlog in the rule of law chapters persisted. On the basis of such a proposal, the Council would decide with a qualified majority and all Member States would be obliged to respect the decision, regardless of the principle of unanimity on decisions of the Intergovernmental Conference.

The Chapter 23 opening benchmarks for Montenegro in June 2021 and for Serbia in January 2014, set at the very beginning of the accession negotiations, envisage that action plans need to be developed and adopted, comprising related timetables and setting out clear objectives and the necessary institutional set-up, in the areas of the judiciary, the fight against corruption, and fundamental rights. Unlike in the case of Croatia's accession negotiations, in line with the new approach, there are 44 interim benchmarks for Montenegro and 50 for Serbia ${ }^{84}$ as additional safeguard measures with the main aim to provide reinforced monitoring and to ensure the overall pace of the process. Apart from the one general benchmark on efficient and continuous monitoring of the implementation of measures contained in the Action Plan for Chapter 23 , other benchmarks are of a different nature and require setting up the legal and institutional framework, capacity building, implementation measures and track record, whereas some of these are also the subject of political will. The same modus operandi is applied with regard to Chap-

\footnotetext{
${ }^{81}$ European Council, 'Conclusions', Brussels, 9 December 2011.

82 Commission, 'Report from the Commission to the European Parliament and the Council on Montenegro's Progress in the Implementation of Reforms' COM(2021) 222.

${ }^{83}$ Council of the European Union, 'General Affairs Council Conclusions', Brussels, 26 June 2012.

${ }^{84}$ See Dragana Lukic, Analysis of Benchmarks for Montenegro through Comparison with Croatia and Serbia (Ministry of European Affairs, January 2018).
} 
ter 24. This new approach with a strong emphasis on Chapters 23 and 24 did not come without some limitations. There is limited availability of clear and unambiguous rules especially under Chapter 23 due to the lack of a hard acquis but also the non-uniform concept of standards on the basis of the Member States' best practices (as shown in the second section of this paper). With regard to the Chapter 24 areas, there was an accelerated development of the acquis. However, contrary to the raison d'être of the new approach - to enhance the accession process and rule of law compliance in particular, the figures presented below show a lack of tangible results and the prevalence of the same levels of alignment. Although Montenegro has been negotiating for more than nine years and Serbia for more than seven, already longer than Croatia which concluded the negotiations in six, membership prospects still remain distant if conditioned by rule of law preparedness, as the new approach envisages.

Chart 3. Rule of law preparedness of Serbia and Montenegro 2015-2021

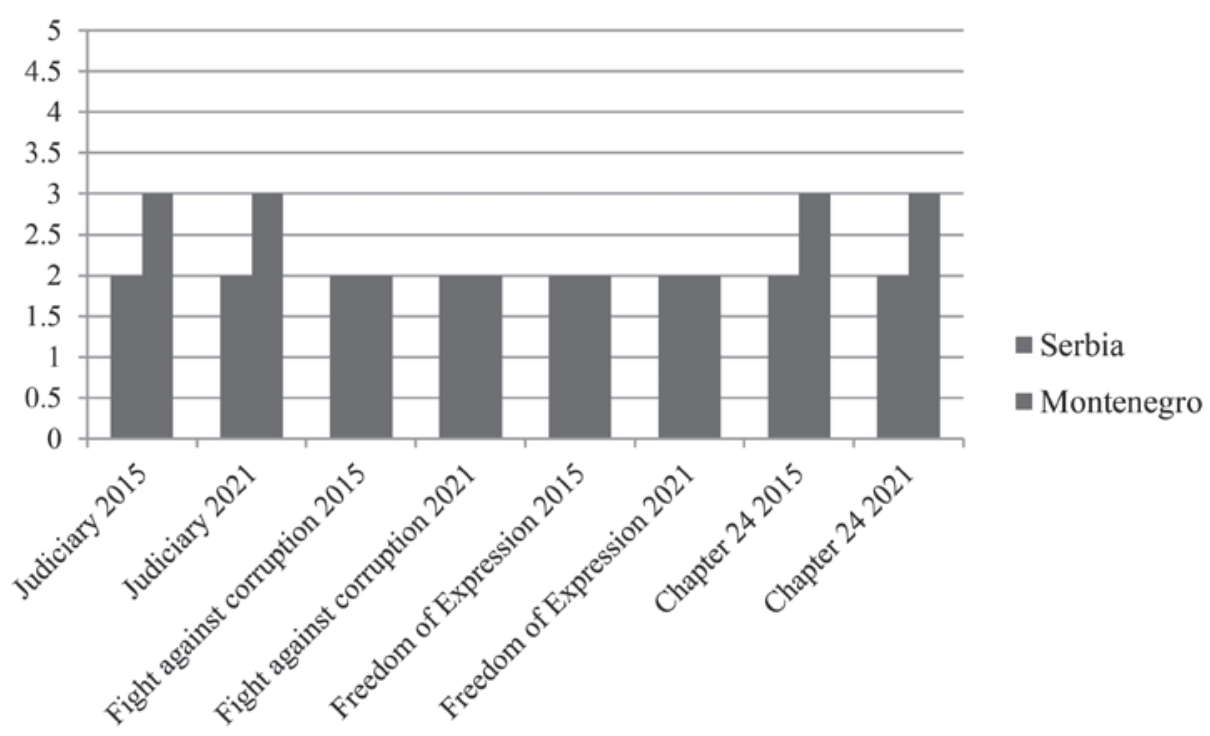

Source: Author's calculations on the basis of the EC Reports

As the European Parliament observed in 2015 when assessing the EU enlargement policy, the accession process has been perceived as a box-ticking exercise focusing more on benchmark fulfilment than on substance. ${ }^{85}$ Moreover, it confirmed that EU integration is also threat-

\footnotetext{
${ }_{85}$ Marko Kmezić, The Western Balkans and EU Enlargement: Lessons Learned, Ways Forward and Prospects Ahead, (European Parliament 2015) 6 <www.europarl.europa.eu/RegData/etudes/IDAN/2015/534999/EXPO_IDA(2015)534999_EN.pdf> accessed 22 July 2021.
} 
ened by the perceived enlargement fatigue coming from inside the Union itself. In November 2015, the European Commission set out a medium-term strategy for EU enlargement policy to cover its mandate, clearly stating that the accession process will be conducted according to the principle 'fundamentals first', with the aim of achieving sustainable results with regard to the key Chapters 23 and 24. In February 2018, the European Commission reaffirmed the firm, merit-based prospect of EU membership for the Western Balkans by adopting the 'Credible Enlargement Perspective for an Enhanced EU Engagement with the Western Balkans' Strategy, ${ }^{86}$ which came almost fifteen years after the last EU-Western Balkans Summit in Thessaloniki in 2003, perceiving the Western Balkans enlargement process as a geostrategic investment for the Union. The Commission acknowledged that there are clear elements of state capture, including links with organised crime and corruption at all levels of government and administration, as well as a strong entanglement of public and private interests. Thus, the rule of law flagship initiative ought to be one of the most important initiatives within the Strategy, where addressing reforms in the area of rule of law remains the most pressing issue for the Western Balkans but also the key benchmark against which the dossiers of these countries will be assessed by the EU. With reference to the membership conditions prescribed by the Lisbon Treaty, rule of law is indicated as a fundamental EU value that the region must embrace 'more strongly and credibly' and requires not only institutional changes but also societal transformation.

When analysing the rule of law requirements set by the EU within the 2018 Strategy, Western Balkan countries are expected to end the sentiment of impunity and inequality by establishing a track record of high corruption cases. In this manner, a visibly empowered and independent judiciary and accountable governments and administrations, together with free media, are essential for bringing about the required societal change. On the side of the EU, the 2018 Strategy indicates that the Commission will work closely with the Western Balkans, this flagship initiative to strengthen the rule of law in the Western Balkans towards ensuring that the judiciary is reformed in line with the highest EU standards and the Copenhagen criteria, also by offering technical and financial support. The rule of law flagship consists of different actions such as analysis of legislation and practice in this field, the establishment of detailed action plans prioritising key issues, advisory missions, close monitoring of implementation, and delivery of concrete results, especially by greater use of the leverage provided in the negotiating process.

\footnotetext{
${ }^{86}$ Commission, 'Communication on a Credible Enlargement Perspective for and Enhanced EU Engagement with the Western Balkans' COM (2018) 65.
} 
Yet there are neither concrete proposals nor a roadmap for strengthening the rule of law, but only some broad policy objectives, and this Strategy should be seen mainly as a platform for closer cooperation with regard to the rule of law reforms ${ }^{87}$ Furthermore, the underlying message in the rule of law initiative is that the Commission plans to make use of all of the leverage provided in the accession talks frameworks for as long as possible, by delaying the Western Balkans accession to the EU in order to avoid any repetition of the scenarios of Hungary and Poland ${ }^{88}$ or when observing clear elements of backsliding in the membership commitments to the rule of law ${ }^{89}$ and persisting problems with organised crime as in the case of Bulgaria.

\subsection{The enlargement's most fundamental - credible perspective}

Still, this new Strategy was not enough to overcome the impasse in the EU's enlargement policy on the Western Balkans that has been running on 'autopilot' for the last fifteen years, ${ }^{90}$ thus in March 2020 the EU once again - or more precisely for the fourth time - formally ${ }^{91}$ introduced new rules on accession negotiations by adopting the new Enlargement Methodology on the basis of the Commission's proposal entitled 'Enhancing the accession process: A credible EU perspective for the Western Balkans'. ${ }^{92}$ This new methodology was put forward mainly for the accession process of North Macedonia and Albania, but later on, in May 2021, the Council agreed on its application to the already opened accession negotiations with Montenegro and Serbia by accommodating certain changes within the existing negotiating frameworks, after both candidate countries expressed their acceptance. ${ }^{93}$

\footnotetext{
${ }^{87}$ Andi Hoxhaj, 'The EU Rule of Law Initiative Towards the Western Balkans' (2021) 13 Hague Journal on the Rule of Law 143, 148.

${ }^{88}$ Heather Grabbe and Stefan Lehne, 'Defending EU Values in Poland and Hungary' (Carnegie Europe 2020) <hhttps://carnegieeurope.eu/2017/09/04/defending-eu-values-in-poland-and-hungary-pub-72988> accessed 23 July 2021.

89 Dariusz Adamski, 'The Social Contract of Democratic Backsliding in the 'New EU Countries' (2019) 56(3) Common Market Law Review 623.

90 Kmezić (n 85) 6.

${ }^{91}$ With the Copenhagen criteria as a starting point, Chapter 23 as the second innovation, and the new approach as the third novelty.

${ }^{92}$ Commission, 'A Credible EU Perspective for the Western Balkans' (Communication) COM (2020) 57.
}

This new proposal by the Commission to reform the EU accession process framework with rule of law as a central accession criterion was based on the French Non-paper 'Reversibility Needed in New Enlargement Strategy' published in November 2019.

${ }_{93}$ Council of the European Union, 'Application of the revised enlargement methodology to the accession negotiations with Montenegro and Serbia' 8536/21, Brussels, 6 May 2021. 
Chapters are reorganised into six clusters and the first cluster 'Fundamentals' focuses mainly on respecting and promoting EU fundamental rights and on reforming independent institutions such as the judicial system, so that the state is able to uphold the rule of law and democratic standards laid out in the Copenhagen criteria. Apparently, this cluster that contains Chapters 23 and 24 and is intended to ensure more credible accession negotiations is the most complex and certainly the most difficult cluster to negotiate, as it is to be opened at the start of the accession process and remains open during the whole process. This fact underlines the importance that the Union has been attaching to the rule of law principle as one of its most significant and cherished values. In this regard, the new Enlargement Methodology with its 'even stronger focus on the fundamental reforms essential for success on the EU path' (in the words of the Commission) inevitably requires political will as a key element of the toolbox and delivering from both sides - Member States must demonstrate decisiveness to move when there is progress, while candidate countries to change and reform. As the rule of law takes the primary role in the process, access to funds for improving various sectors is also tied to progress in the rule of law.

This need for further reform of the accession process came after the 2019 French veto of the proposal of the European Commission to open accession negotiations between the EU and North Macedonia and Albania, ${ }^{94}$ supported by Denmark and the Netherlands as well. Two main arguments raised with regard to the veto were the following: first, the EU needs to strengthen its existing policies and institutions before adding any new members; and, second, the enlargement policy and accession talks process are flawed, as there is no guarantee that the candidate state will subscribe to the Copenhagen criteria and uphold the rule of law and the EU liberal democratic values once they join the EU ${ }^{95}$ On this occasion, French President Macron stated that these countries are implementing EU legislation without transforming, thus implying that the process of Europeanisation based on exporting the principles of democracy and rule of law has failed to bring the required changes and prepare the countries for EU membership. Nevertheless, the background to this decision reveals that it was made also due to the fourth Copenhagen criterion - 'absorption capacity of the Union' that refers to the capability to include new members. The introduction of this condition provides the possibility to diverge from the procedure and make a political decision if

\footnotetext{
${ }_{94}$ According to the published conclusions from the European Council meeting on 17 and 18 October 2019, the European Council will revisit the issue of enlargement before the EU-Western Balkans-summit planned for May $2020<$ https://www.consilium.europa.eu/ media/41123/17-18-euco-fi nal-conclusions-en.pdf> accessed 29 July 2021.

${ }^{95}$ Hoxhaj (n 87) 158.
} 
a country fulfils the membership criteria while the Union itself, for different reasons, is not prepared for further enlargement. Hence, besides the lack of transformation that President Macron referred to, it was also about inner limitations within the Union and divergence with regard to its further enlargement, also questioning the strength of the EU's transformative power. ${ }^{96}$ In the light of the ongoing developments within the EU - particularly in Hungary and Poland - the main rationale behind this decision was based on the notion that, once a country becomes a Member State of the EU, there are no adequate mechanisms to address subsequent backsliding of democratic standards and the rule of law. ${ }^{97}$

In accordance with these new requirements set by the new Enlargement Methodology, North Macedonia has achieved good progress in the key areas under the first cluster that was followed up by the Council of the EU decision in March $2020^{98}$ finally adopting a conclusion to open accession negotiations with both North Macedonia and Albania, albeit without setting a date for the first intergovernmental conference. Nevertheless, until now the EU has failed to reach an agreement on approving the negotiations frameworks with North Macedonia and Albania as well, ${ }^{99}$ which proves the claim that accession is in fact a political process involving discretion about timing and the different weights given to the various factors influencing the decision above and beyond the rule of law, regardless of its central role as prescribed. The Brdo Declaration

\footnotetext{
${ }^{96}$ An analysis of the public discourse on this decision leads to the conclusion that France was the main opponent. In an interview with The Economist published on 7 November 2019, President of France Emmanuel Macron said: 'We can't make it work with 27 of us (...). Do you think it will work better if there are 30 or 32 of us? And they tell me: "If we start talks now, it will be in ten or 15 years". That's not being honest with our citizens or with those countries. I've said to them: "Look at banking union". The crisis in 2008 with these big decisions; end of banking union in 2028. It's taking us 20 years to reform. So even if we open these negotiations now, we still won't have reformed our union if we carry on at today's pace'. The Economist, 'Emanuel Macron in His Own Words' The Economist (London 7 November 2019) <www.economist.com/europe/2019/11/07/emmanuel-macron-in-hisown-words-english> accessed 28 July 2021. Rym Momtaz and Andrew Gray, 'Macron Urges Reform of 'Bizarre' System for EU hopefuls' Politico (Toulouse 16 October 2016) <www. politico.eu/article/macron-urges-reform-of-bizarre-system-for-eu-hopefuls/> accessed 29 July 2021.

${ }^{97}$ See Melanie Smith, 'Staring into the Abyss: A Crisis of the Rule of Law in the EU' (2019) 25(6) European Law Journal 561.

${ }_{98}$ Council of the European Union, 'General Affairs Council conclusions', Brussels, 25 March 2020.

99 According to the GAC press release <www.consilium.europa.eu/en/meetings/gac/2021/ $06 / 22 />$, it was not possible for the Council to reach an agreement on approving the negotiations frameworks with North Macedonia and Albania, due to the Bulgarian veto imposed on North Macedonia which is caused by requirements that are not in line with the established accession criteria such as (non)recognition of the official language.
} 
from the EU-WB Summit held in October $2021^{100}$ continued to be vocal on 'the primacy of democracy, fundamental rights, and the rule of law' with regard to "the enlargement process and its decisions taken thereon, based upon credible reforms by partners, fair and rigorous conditionality and the principle of own merits' - unlike the 2018 Sofia and 2020 Zagreb Summit Declarations that spoke only of the European perspective for the region. Nevertheless, these words did not sound promising and incentivising, having in mind that the 'decision taken thereon' to which the EU points as its commitment has not been fulfilled for reasons which are not related to the prioritised rule of law.

\section{The case of North Macedonia as a test for the EU's credibility in promoting the rule of law: lessons learned (or repeated mistakes)}

The case of North Macedonia's accession towards the EU is a drastic one, questioning the credibility of the enlargement process. By signing the Stabilisation and Association Agreement in $2001^{101}$ as the first country from this region, North Macedonia expressed its aspiration for EU integration, while the official application for membership was submitted in 2004. In November 2005, the Commission responded positively to the request ${ }^{102}$ and in accordance with the conclusions of the European Council held in December 2005, North Macedonia was officially granted the status of candidate country for membership on the basis of the significant progress made towards meeting the Copenhagen political criteria and with regard to the terms set by the SAA. ${ }^{103}$ The following section will examine the rule of law conditionality in the case of North Macedonia in order to explain the causality with the credibility of the promised incentive which is (progress towards) EU membership.

\subsection{Rule of law reforms of the 'early and eager' Europeaniser}

With reference to the rule of law, Article 74 SAA which is still the existing legal framework regulating the relations between North Macedonia and the EU sets twofold obligations for both North Macedonia and the EU:

\footnotetext{
100 Brdo Declaration, 6 October 2021 <www.consilium.europa.eu/en/press/press-releases/2021/10/06/brdo-declaration-6-october-2021/> accessed 25 November 2021.

101 Stabilisation and Association Agreement between the European Communities and their Member States, of the one part, and the Former Yugoslav Republic of Macedonia, of the other part [2004] OJ L84/13.

102 Commission, 'Opinion on the application from the former Yugoslav Republic of Macedonia for membership of the European Union' (Communication) COM (2005) 562.

103 European Council, 'Presidency Conclusions', Brussels, 15-16 December 2005.
} 
Within their cooperation in the field of justice and home affairs, the Parties shall pay particular attention to strengthening institutions at all levels in the areas of administration in general and with regard to the enforcement of law and justice mechanisms in particular. This especially includes strengthening the rule of law.

Cooperation in the field of justice will focus especially on the independence of the judiciary, improving its effectiveness and training of the legal professions.

Within the 2008 Accession Partnership ${ }^{104}$ as an instrument of the Stabilisation and Association Process, priority areas where further progress was needed were identified in order to be assessed on the basis of the set benchmarks that referred to the adoption of appropriate legislation and implementation, in accordance with the structure of the Copenhagen criteria. The rule of law areas were contained within the political criteria and partly in Chapter 23 whose content at that moment were still in the process of being determined. With regard to the area of the judiciary, it was stated that further development of the initial and continuous training of judges and public prosecutors in the Academy for Training of Judges and Prosecutors was needed along with the setting up of new judicial structures and allocating appropriate funds for their full operation and improving their efficiency as well as ensuring the proper and complete execution of judgments. Priority areas also included the fight against corruption, where the proper implementation of the recommendations of national anti-corruption institutions such as the State Commission for the Prevention of Corruption and the State Audit Office was emphasised, as well as those of international bodies such as the Group of States against Corruption (GRECO). Moreover, the fulfilment of the set benchmarks required the strengthening of the administrative capacities needed to implement the rules for financing political parties and election campaigns and the introduction of effective sanctions in the event of violations. In terms of fundamental rights, the main focus was put on the protection of human and minority rights. In that context, the Accession Partnership targeted eight key priorities of which three were related to the rule of law: a sustained track record on the implementa-

\footnotetext{
${ }^{104}$ Council Decision 2008/212/EC of 18 February 2008 on the Principles, Priorities and Conditions Contained in the Accession Partnership with the Former Yugoslav Republic of Macedonia and Repealing Decision 2006/57/EC [2008] OJ L80/32. The Accession Partnership upgraded the 2008 European Partnership and it was established under the Thessaloniki 2003 Agenda for the Western Balkans. The legal basis for concluding European partnerships and accession partnerships as instruments of the conditionality policy is contained in the Council Regulation establishing the European Partnerships within the Stabilisation and Association Process (Council Regulation (EC) No 533/2004 of 22 March 2004 on the Establishment of European Partnerships in the Framework of the Stabilisation and Association Process [2004] OJ L86/1).
} 
tion of judiciary reforms and strengthening the independence and overall capacity of the judicial system, together with reform of the prosecutorial system (Chapter 23), a track record with regard to the implementation of anti-corruption legislation (Chapter 23), and the proper implementation of the law on the police (Chapter 24). Hence, the Government in March 2008 adopted an action plan for fulfilling the required priorities. Building on the previously elaborated approach towards the rule of law in the enlargement process, these priorities certainly switched the focus to the rule of law and building constituency instead of a framework, thus speaking of track record and capacity, which would then become the centre of gravity in the (last phase of) accession negotiations with Croatia.

On the basis of the implementation of the priorities set with the Accession Partnership as benchmarks for assessing the progress achieved, in 2009 the European Commission issued the first recommendation for opening accession negotiations with the country. ${ }^{105}$ The country has 'substantially addressed the key priorities of the Accession partnership regarding the reform of the police, the judiciary, public administration and corruption' and 'ensured the stability of institutions guaranteeing the rule of law and respect of fundamental rights' although the given period time-wise was limited to establish a track record. However, these conditions were accompanied by other conditions too, mainly maintaining good neighbourly relations including reaching a common solution for the name issue with Greece under the auspices of the UN. The country was made subject to the 'Copenhagen Plus' criteria, which relate to specific problems of the region, including the resolution of bilateral disputes. In that manner, the Commission's recommendation for opening accession negotiations was not made effective by the Council of the EU that actually decided to postpone the process due to the inability to reach unanimity caused by the Greek blockade. ${ }^{106}$ It remains an academic conundrum whether the accession process of North Macedonia would have been performed in line with the same approach reflected in the case of Croatia and whether the Act of Accession would have covered both countries. For comparison, within the same Enlargement Package in 2009, ${ }^{107}$ the Commission identified more rule of law shortcomings with regard to Croatia than North Macedonia - for example, Croatia had shown weaker progress in the fight against corruption (some progress) while North Macedonia had achieved good progress. Accordingly, the decision to postpone the accession negotiations with North Macedonia despite progress

\footnotetext{
${ }^{105}$ Commission, 'Enlargement Strategy and Main Challenges 2009-2010' (Communication) COM (2009) 533.

${ }^{106}$ Council of the European Union, 'General Affairs Council Conclusions', Brussels, 7-8 December 2009.

107 Commission (n 105).
} 
in the fulfilment of the rule of law priorities compromised its central role in the enlargement policy and diverted efforts towards bilateral issues.

This decision represents a precedent in the enlargement policy, due to the fact that it was the first time the Council did not accept the Commission's recommendation which was based on the accession conditions, thus in some way undermining its authority in the process and in the process itself. Moreover, starting from the basic thesis on the division of power in the EU, according to which the Commission represents the supranational element while the Council stands for intergovernmental interests, this precedent meant that the decision is primarily political and serves the interests of the Member States. Besides Croatia, the country has been "an early and eager "Europeaniser" in the Western Balkans' ${ }^{108}$ that engaged in a high legislative activity to bring its institutions and policies in line with the EU and earned a positive recommendation to open the accession negotiations, only to be vetoed by a Member State on the basis of an issue which is not part of the Copenhagen criteria widely accepted as the main accession conditions. In light of the power of momentum, the 2008 Accession Partnership and its main priorities set by the European Commission as requirements for obtaining a negotiation date with the EU has become redundant with the passage of time.

\subsection{Writings on the wall}

In order to maintain the credibility of the process, in 2012, that is, three years after the initial conclusion of the Council to postpone the decision to open negotiations, the European Commission launched the High-Level Accession Dialogue (HLAD) as a new instrument of the accession process that focuses mainly on the rule of law reforms, which were at the same time a priority in the accession process of Croatia - the period of the post-signing of the Act of Accession, and Montenegro opened accession negotiations. The introduction of HLAD was an attempt to introduce new dynamics in the reform process for EU accession and thus to strengthen confidence and support for the European perspective of the country, as well as an incentive to work harder on achieving and implementing the reform processes and resolve the dispute with Greece. The instrument replicated the established model of negotiations, adapted to the context of the accession of the country faced with a stalemate, with the Commission strongly emphasising the importance of policy reforms related to the rule of law such as the protection of freedom of expression in the media. Hence, it was reiterated as being necessary to improve the independence, efficiency and professionalism of the judiciary, to

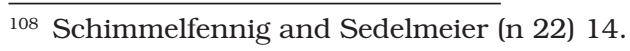


strengthen anti-corruption measures and their consistent implementation, and to increase efficiency and transparency in the management of investigative techniques for communications surveillance and promoting inter-community dialogue.

The dynamics of this process was most noticed during 2012, and the heightened activity led to the fourth positive recommendation for opening negotiations. Moreover, in order to consolidate the pace and sustainability of the reforms undertaken within the HLAD, to reduce the risk of reversibility of the whole process and to strengthen the credibility of the EU, the Commission in the 2012 Enlargement Strategy ${ }^{109}$ expressed its readiness to prepare a draft negotiating framework for the country, while taking into account the need to resolve the name dispute in the early stages of accession negotiations. In fact, this proposal envisaged parallel negotiations on alignment with the EU acquis and negotiations on resolving the name dispute, where HLAD had appeared as an instrument to overcome the veto. The Council reiterated its view that the political criteria were sufficiently met, but also that it would examine the possibility of opening membership negotiations under the next Presidency. ${ }^{110}$ This expression sounded promising as the Council asked the Commission to prepare a progress report for the country by Spring 2013 and if the Commission's assessment was positive, the Council would decide on this issue in June and would approve further steps to open negotiations.

However, the situation on the ground in terms of meeting the political conditions worsened, which called into question the process of implementing reforms in priority areas and revealed the existence of internal problems in the areas of democracy and the rule of law, which over time have become a significant factor for the country's future integration into the EU. Hence, by placing the name dispute as the main catalyst for the process, the fulfilment of the Copenhagen criteria was compromised and 'particular bilateral issues which have little to do with the formal membership conditions have inhibited the accession process'.111 At the GAC meeting in June 2013, the issue of opening accession negotiations with the country was not even put on the agenda at all, despite the report prepared by the Commission. The situation culminated in 2015 when the country received a 'frozen recommendation' by the Commission ${ }^{112}$ as the wiretapped conversations revealed 'state capture' characterised

\footnotetext{
109 Commission, 'Enlargement Strategy and Main Challenges 2012-2013' (Communication) COM (2012) 600.

${ }^{110}$ Council of the European Union, 'General Affairs Council Conclusions,, Brussels, 11 December 2012.

${ }^{111}$ Schimmelfennig and Sedelmeier (n 22) 10.

112 Commission, Commission Staff Working Document - The Former Yugoslav Republic of Macedonia Report 2015 SWD(2015) 212.
} 
by systemic rule of law issues ${ }^{113}$ especially with regard to the judiciary, independent bodies, security services, media and elections. The EU process in the country was reduced to mediation in overcoming the crisis through the Political Agreement of June/July 2015 and the Urgent Reform Priorities as instruments.

Table 1. Progress in areas under Chapter 23 MKD 2009 - 2015

\begin{tabular}{|c|c|c|c|}
\hline & Judiciary & Anti-corruption & $\begin{array}{c}\text { Fundamental Rights/ } \\
\text { Freedom of Expression }\end{array}$ \\
\hline $\mathbf{2 0 0 9}$ & 2 & 4 & 2 \\
\hline $\mathbf{2 0 1 5}$ & -1 & 0 & -1 \\
\hline
\end{tabular}

Source: Author's calculations based on EC (Progress) Reports

In the previous waves of enlargement, gate-keeping access to negotiations was the most powerful tool of EU conditionality ${ }^{114}$ but this time it proved to be counterproductive because it was not made on the principle of merits and credibility. According to the 'fundamentals first' principle, rule of law and fundamental rights were defined as areas subject to strengthened monitoring, but precisely in these areas North Macedonia was stagnating or backsliding. Moreover, the Commission stressed the gap between the good level of legal alignment and backsliding in key areas: the first was due to the fact that the country had been in the process of stabilisation and association longer than the other countries in the region, while the second referred to inconsistencies in terms of EU enlargement methodology along with a difference between formal rule adoption and genuine internalisation of EU values and standards during the accession process. Hence, one of the functions of the process should also be semantic harmonisation. ${ }^{115}$ Along with this, monitoring and assessment mechanisms in terms of the Commission's Reports came into question because, prior to this report, since 2009, each report had emphasised strengths and weaknesses, but the Commission provided a clear recommendation to start accession negotiations which was also positively assessed by the European Parliament.

\footnotetext{
${ }^{113}$ Recommendations of the Senior Experts' Group on Systemic Rule of Law Issues Relating to the Communications Interception Revealed in Spring 2015, Brussels, 8 June 2015 $<$ https://ec.europa.eu/neighbourhood-enlargement/system/files/2016-12/20150619_ recommendations_of_the_senior_experts_group.pdf> accessed 24 December 2021.

114 Nikolova (n 41) 400.

115 Siniša Rodin, 'Discourse and Authority in European and Post-Communist Legal Culture' (2005) 1 Croatian Yearbook of European Law and Policy 1, 15.
} 
Having in mind the proclaimed two-sided obligations for the country and the EU, stipulated in the SAA as well as by the overall logic of the incentive model for the Europeanisation process, both sides bear responsibility for the reversibility of the reform process with a focus on the priorities, including the rule of law areas, which had appeared since 2010 which coincides with the stalemate in the accession negotiations. The lack of a credible membership perspective on the side of the EU with bilateral issues as the greatest impediments has undermined the rule of law conditionality. In the absence of EU leverage, instead of implementing the rule of law reforms that require great efforts but also weaken the power of political elites, the outcome of the cost/benefit calculations of the government led to engaging in state capture as the opposite of the rule of law. The situation showed how important political will is when it comes to rule of law reforms: for example, the Commission assessed that the 'achievements of the last decade's reforms are being undermined by real and potential political interference in the work of the judiciary'. ${ }^{116}$ In terms of the fight against corruption, the country has 'set up the necessary legislative and institutional framework over the last decade as well as developing a track record of both prevention and prosecution'117but 'the capacity to effectively address it [corruption] is currently being undermined by a lack of political will and political interference in the work of the relevant bodies, which is hampering their ability to act proactively and non-selectively, especially in high-level cases.' ${ }^{18}$ The same assessment was relevant regarding freedom of expression where backsliding was noted, although 'the legislative framework has been overhauled in recent years and is aligned with both the acquis and international standards.' ${ }^{119}$ Hence, although the legislative and institutional framework was all set up, the government provided control over the crucial stage of otherwise EU-harmonised implementing legislation while there was still no complete rejection of the EU integration process.

Not only was the EU unable to counter the rise of state capture but it was also (inadvertently) contributing to it ${ }^{120}$ by having no means to intervene at least while the name issue persisted in the form of a Greek veto on which the EU institutions were not aligned ${ }^{121}$ yet not being able

\footnotetext{
116 Commission (n 112) 12.

117 ibid, 15.

118 ibid, 15.

119 ibid, 20.

120 See Solveig Richter and Natasha Wunsch, 'Money, Power, Glory: The Linkages between EU Conditionality and State Capture in the Western Balkans' (2009) 27(1) Journal of European Public Policy 41.

${ }^{121}$ Having in mind the situation explained above where the European Commission and European Parliament recommended the start of the accession negotiations, but the Council
} 
to address. In this context, it is worth mentioning that the International Court of Justice found that the name dispute should not have been used by Greece to object to the country's admission to international organisations, ${ }^{122}$ thus raising questions on respect for the rule of law in relation to the Council of the EU veto. Turning a blind eye to these tendencies can also be explained on the ground of enlargement fatigue expressed through the stalemate that was openly confirmed by the Commission in $2014^{123}$ as one of many signals and indications of the reduced credibility of the promise in the EU's conditionality. Thus, the situation with rule of law backsliding was an argument to keep the doors closed. Nevertheless, ensuring the rule of law and democratic transition through the enlargement process is not only in the interest of the candidate countries but also in that of the EU. State capture - or when the law does not rule caused deep political crisis and instability with the potential to spill over beyond the country, where the difficult process of government formation reached a critical point during the 27 April 2017 attacks in Parliament, which were condemned in the strongest terms by the EU. ${ }^{124}$ At the same time, the migrant crisis in 2015 brought the return of geopolitics and clearly demonstrated the strategic importance of EU enlargement together with the urgent need to adopt serious and credible prospects of EU membership. An attempt to do so was the new Enlargement Methodology which recognises the geopolitical aspects of the process, whereas the prospect of membership is explained as a 'geostrategic investment', and the importance of the enlargement process is underlined "particularly at times of increased geopolitical competition.' ${ }^{125}$

\section{3 (Not) another vicious circle}

The New Government in North Macedonia formed in 2017, elected after the political crisis, demonstrated determination to commit to implementing reforms in key areas under the rule of law but also to overcome the name dispute with Greece in the light of the renewed EU promise for opening accession negotiations. In the context of the new momentum,

\footnotetext{
opposed.

${ }^{122}$ International Court of Justice, Judgment of 5 December 2011 - Application of the Interim Accord of 13 September 1995 (the former Yugoslav Republic of Macedonia v Greece) para 113.

${ }^{123}$ Commission, 'Press Release - The Juncker Commission: A Strong and Experienced Team Standing for Change', Brussels, 10 October 2014.

${ }^{124}$ Euroactiv, 'Violence Erupts as Protesters Storm Macedonia Parliament' (28 April 2017) $<$ www.euractiv.com/section/enlargement/news/violence-erupts-as-protesters-stormmacedonia-parliament/> accessed 26 November 2021.

${ }^{125}$ Commission, 'Enhancing the Accession Process - A Credible EU Perspective for the Western Balkans' (Communication) COM (2020) 57.
} 
EU Commissioner Johannes Hahn admitted that '[t]en years ago, the country was the best pupil in the class [in terms of pro-EU reforms]' and the EU's handling of the name dispute with Greece 'was clearly not helpful for stabilizing the country' so that the EU 'should have learned their lesson and find a solution at last to start negotiations'. ${ }^{126}$ Urgent Reform Priorities were set as main benchmarks for the reform process which required implementation of the legislative framework and were more focused on real results in the field and establishing a track record instead of simple rule adoption. The country's determination to advance the EU reform agenda has delivered tangible results in terms of the rule of law as the core objective of the accession process. The political will to pursue reforms in this area on the basis of the European perspective turned out to be one of the most important ingredients - for example, the Commission noted that 'the backsliding of previous years has started to be reversed through decisive steps taken in recent months to start restoring the independence of the judiciary' and 'there is an improved climate for media and journalists are more ready to criticize misbehavior of officials and censorship. ${ }^{127}$ Furthermore, the long-standing name dispute was resolved in 2018 with the signing of the Prespa Agreement ${ }^{128}$ according to which the country accepted 'Republic of North Macedonia' as its official and constitutional name. In June 2018, the Council adopted conclusions upon the Commission's recommendation and agreed to respond positively to the progress made by North Macedonia, but set out the path towards opening accession negotiations in June 2019, depending on progress made in certain key areas under the rule of law, such as judicial reform, reform of intelligence and security services, and public administration reform. ${ }^{129}$ Despite all the efforts and political capital invested in fulfilling the accession criteria with a special focus on the rule of law and solving the name issue as a pre-condition for accession negotiations, North Macedonia found itself again in the EU waiting room where the main reason for such a temporary setback was the French veto discussed above, issued over concerns about EU transformative power.

\footnotetext{
${ }^{126}$ Andrew Rettman, 'EU Sees "Momentum” on Macedonia Name Dispute' EU Observer (Brussels, 12 June 2017) <https://euobserver.com/enlargement/138199> accessed 28 August 2021.

${ }^{127}$ Commission, Commission Staff Working Document, 'The former Yugoslav Republic of Macedonia 2018 Report' SWD(2018) 154.

${ }^{128}$ Agreement - Final Agreement for the Settlement of the Differences as Described in the United Nations Security Council Resolutions 817 (1993) and 845 (1993), the Termination of the Interim Accord of 1995, and the Establishment of a Strategic Partnership between the Parties <https://vlada.mk/sites/default/files/dokumenti/spogodba-en.pdf> accessed 28 November 2021.

${ }^{129}$ Council of the European Union, 'General Affairs Council Conclusions', Brussels, 26 June 2018.
} 
In a number of different press releases and public statements, the French government brought forward two principal arguments justifying its opposition: ${ }^{130}$ the perceived need to reform the accession procedures before any new countries can join the EU, and a supposed trade-off between the widening and deepening of the EU more generally. As argued above, even if these arguments are proclaimed as acceptable, this decision undermined EU leverage to insist on reforms within the Europeanisation process and activates the fourth often forgotten Copenhagen criterion which refers to the absorption capacity of the Union, while at the same time it reveals that the EU had fallen out over its biggest foreign policy project - expansion into the Western Balkans through the enlargement policy. European Council President Donald Tusk and European Commission President Jean-Claude Juncker criticised the French move, even calling it 'a historic mistake. ${ }^{131}$ Despite the disappointment, North Macedonia adapted to the new Enlargement Methodology and continued the EU reform agenda so the Council in March $2020^{132}$ finally reached a decision to open accession negotiations with North Macedonia and Albania.

But instead of 'lessons learned' in the words of Commissioner Hahn, the EU is facing repeated mistakes as the decision to open the long-delayed accession negotiations with North Macedonia from March 2020 is still not being implemented due to a blockade imposed by Bulgaria on adopting the negotiation framework and scheduling the first intergovernmental conference ${ }^{133}$ on claims over its history, language and identity. This dispute raised by the Bulgarian side implicitly compromises the ac-

\footnotetext{
130 'Emmanuel Macron's EU Accession Veto Is a Historic Mistake. Bloc Should Open Talks with North Macedonia and Albania, then Reform Itself Financial Times (London, 21 October 2019) <www.ft.com/content/eda39e1e-f3eb-11e9-b018-3ef8794b17c6> accessed $28 \mathrm{Au}$ gust 2021.

131 'Blocking Negotiations with North Macedonia and Albania Is A 'Huge Historical Mistake' Brussels Times (Brussels, 18 October 2019) <www.brusselstimes.com/news/eu-affairs $/ 74241 /$ jean-claude-juncker-deplores-europes-failure-to-start-eu-enlargement-negotiations/> accessed 28 August 2021.

${ }^{132}$ Council Decision.

${ }^{133}$ Before the October 2019 European Council meeting, the Bulgarian Government adopted a Framework position, confirmed by a Declaration endorsed by all political parties in the Bulgarian parliament. This document was followed by a Statement of the Bulgarian Government annexed to the Council conclusions of March 2020, focusing on the general conditions, the conditions for the first intergovernmental conference and Chapter 35. The statement set out the conditions it insisted should be met by North Macedonia before accession negotiations could begin. These included an acceptance by North Macedonia that its language had Bulgarian roots, and that a 'Macedonian language' or ethnicity did not exist before 1944. It also demanded an end to what it called 'state-sponsored anti-Bulgarian ideology', as well as renouncing any claims to the 'existence of a Macedonian minority' in Bulgaria, and set out what can only be described as a one-sided interpretation of the region's history.
} 
cession criteria of the Cluster Fundamentals on democratic institutions and the rule of law and goes against the principles of the new Enlargement Methodology endorsed by the Council, undermining the authority of the European Council's decisions such as the one from March 2020 for opening accession negotiations with North Macedonia. Moreover, it is also contrary to the founding values of the EU stipulated in Article 2 TEU, also having in mind that the negotiating framework should avoid any contradictions to the EU acquis, as Article 4 TEU states that 'the Union shall respect the equality of Member States before the Treaties as well as their national identities, inherent in their fundamental structures, political and constitutional, inclusive of regional and local self-government'. As a Union of laws and based on mutual and sincere cooperation, the EU is highly dependent on the rule of law $^{134}$ that includes implementation of its own decisions, and thus the Bulgarian blockade compromises the Union's interests for its narrow national interests and the state of the Union itself. This situation rang the bell inside the EU and although the decision for opening accession negotiations with North Macedonia still lacks actual implementation, a certain shift regarding the enlargement policy has been noticed, in terms of its prioritising and awareness of the risk of losing the region, along with the importance of the Europeanisation process for both sides - the EU and the Western Balkans. ${ }^{135}$

\footnotetext{
${ }_{134}$ Magen (n 72) 1050.

${ }^{135}$ On the occasion of the meeting with the Prime Minister of North Macedonia Zoran Zaev, President of France Emmanuel Macron stated that the decision for opening accession negotiations must be implemented: The European Union decided in March last year to start negotiations with your country and now is the time to concretize that decision and France actively supports it. North Macedonia deserves to start negotiations without delay'.

Élysée, 'Déclaration conjointe du Président Emmanuel Macron et du Premier Ministre de la République de Macédoine du Nord Zoran Zaev' (Paris, 10 June 2021).

Following the discussion of the June 2021 General Affairs Council, the Dutch government also expressed readiness to support the official opening of the accession negotiations, in line with the decision from March 2020: PM Mark Rutte doorstep statement at the EUWB Summit in Brdo, Slovenia on 6 October 2021: 'I'm really not happy with the fact that the accession talks with North Macedonia are still blocked' <https://mobile.twitter.com/nlateu/status/1445662320307232774?ref_src=twsrc\%5Etfw> accessed 26 November 2021.
} 
Table 2. Comparative overview of the rule of law progress and preparedness

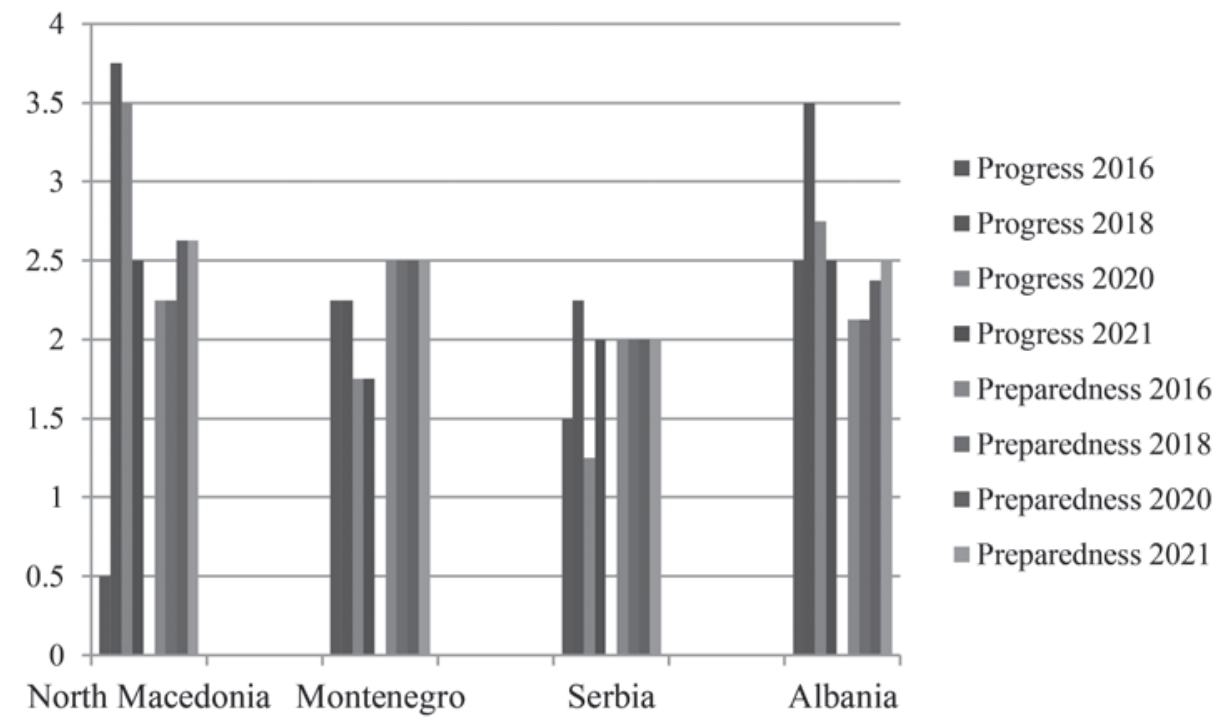

Source: Author's calculations based on the EC 2021 Report within the Enlargement Package ${ }^{136}$

In general, the comparative evidence highlights the importance of credibility. Even if incentives are strong in principle, they fail to affect rule adoption and compliance if they lack credibility. ${ }^{137}$ In the case of North Macedonia and Albania in 2018, the opening of the accession negotiations as a highly credible incentive stimulated progress and has proven capable of overcoming the considerable domestic costs related to the rule of law reforms which at the level of preparedness are most visible in 2020 and 2021 due to the time needed for their internalisation. On the other side, a decrease in the certainty of this incentive caused by a delay in the actual start of the accession negotiations due to the non-adoption of the negotiating framework caused stagnation in the level of progress. In terms of preparedness, North Macedonia in 2021, as in 2020, still has the 'best score' - better than the countries that are already negotiating such as Montenegro and Serbia, while Albania is at the same level as Montenegro and is better than Serbia. In this way, North Macedonia demonstrates a steady commitment to deliver on reforms, but indicators

\footnotetext{
${ }^{136}$ Kosovo and Bosnia and Herzegovina are excluded from the analysis due to their status as potential candidate countries.

${ }^{137}$ Schimmelfennig and Sedelmeier (n 22) 15.
} 
on the level of progress show that the pace cannot be maintained without opening accession negotiations as an incentive for further advancement.

Hence, the ability to fulfil the obligations of membership by rule adoption and implementation of the EU acquis in order to open the accession negotiations is not only a technical conditionality requirement but also a highly political affair. ${ }^{138}$ Not only will any further lack of incentive impact on the level of alignment of North Macedonia and Albania, it will also affect the overall process in the region which is visible in the case of Montenegro and Serbia - a loss of credibility is the most important factor in the decline of the Europeanisation effects of the EU's enlargement policy. According to the new Enlargement Methodology, more credibility is indicated as the first condition for reinvigorating the accession process to deliver its full potential, but it is emphasised that it needs to rest on solid trust, mutual confidence and clear commitments on both sides. ${ }^{139}$ In that context, this also means that the EU delivers on its unwavering commitment to a merit-based process: when partner countries meet the objective criteria and the established objective conditions, the Member States will agree to move forward to the next stage of the process and 'all parties must abstain from misusing outstanding issues in the EU accession process. ${ }^{140}$

Without enhanced credibility as one of the main challenges and tasks on the side of the EU, it is unrealistic to expect any significant changes or a transformative effect of the revised methodology that aims to provide a more dynamic process. Credibility can be reinforced only through a strict and merit-based focus on fundamental reforms, including the rule of law which is essential for real transformation and progress on the EU path. Finally, if the greatest impediments to North Macedonia's accession progress are not the rule of law criteria but mainly the unresolved neighbourly issues, then that affects the rule of law conditionality and undermines its central role in the framework of the EU enlargement policy towards the Western Balkans and its overall credibility. The previous domination of bilateral issues as explained above encouraged this further hijacking of the accession process for national interests, but its effects, as elaborated above, were damaging for both sides - for North Macedonia as a candidate country but also for the EU. Contrary to the previous strategies to trade stability for the rule of law, it has been shown that stability and rule of law go hand in hand. The Western Balkans is a region that is still overwhelmed with open disputes that can be overcome only on the basis of the European perspective. Giving

\footnotetext{
138 Kmezi , (n 85) 12.

139 Commission (n 92) 2.

140 ibid.
} 
prominence to the open disputes in the accession process would create instability which goes against the raison d'etre of this complex European unification process. It is a vicious circle that must be ended because it is leading nowhere - either for the Western Balkans (or any other countries within the enlargement policy), or for the EU.

\section{Conclusions}

Enlargement means not only the territorial expansion of EU membership rights and obligations to other European states and peoples, but it also triggers new policy demands and affects the EU's legal corpus. In this regard, the paper has argued that the rule of law is at the core of the accession process but Europeanisation in that regard is a twofold challenge for both the EU and the candidate countries. The EU acquis expands over time and the conditions to be met by candidate countries evolve too. They include complex areas such as the judiciary, the fight against corruption, and fundamental rights in relation to which the process does not end only in the adoption of rules, but requires the internalisation of EU norms and standards as the rule of law forms the backbone of common EU values. The extension of EU membership to Central and Eastern Europe has been a process of fundamental domestic change in response to EU rules and regulations but (some of) the states that entered the EU from 2004 onwards did not finish the transformation process on the date of accession. Post-accession experience with regard to rule of law compliance and conditionality imposed some internal challenges for the EU that have had a major influence on the EU's external upholding and promotion of the rule of law within the enlargement policy towards the Western Balkans.

Hence, not only the systemic weaknesses with regard to the rule of law in the Western Balkans but also the integration process within the EU are the reasons for an even stronger emphasis on democracy and the rule of law. However, this evolving normative basis for EU enlargement has raised issues of double standards that have consequently undermined the credibility of the Union's commitments to the norms and values it advocates in relation to the candidate countries/applicants. It ultimately questions the effectiveness of the transformation agenda and the role of the EU. As the case study on the accession process of North Macedonia shows, the reform process bears responsibilities for both sides - the EU and the candidate country. Inconsistency regarding the objective validation of the Copenhagen criteria as the main basis of the conditionality policy and the domination of other issues have undermined the presumed transformative power of the EU. Changed rules of the accession process and upgraded rule of law conditionality introduced by the new Enlargement Methodology are also related to the fulfilment of 
the fourth Copenhagen criterion which refers to the absorption capacity for further enlargement. Along with the particular needs and problems affecting the rule of law in the countries of the Western Balkans, the evolving state of EU integration and of its acquis, the number of states the Union comprises when it enlarges, the internal challenges the Union is facing, support from within for the enlargement process and even some narrow national interests all contribute to potential alterations of the enlargement methodology and to the prominence of some particular features at any given time, influencing the decision beyond and above rule of law conditionality.

At the same time, not only the conditions but also the credibility of the European perspective and the feasibility of the promise of membership have changed from the CEE to the Western Balkans context, which stands out as a crucial pre-condition for pre-accession compliance. The enlargement policy towards the Western Balkans is characterised by triple 'C fragilities' - weakened conditionality, credibility loss and higher costs for domestic political actors. In terms of the Western Balkans, rule of law adaptation costs are higher since these countries started farther away from the EU standards which in the meantime transformed into moving targets, while the credibility of the process is much lower as the membership perspective is more distant and even uncertain. The EU should particularly discourage bilateral issues from dominating the enlargement agenda. On the one hand, because they undermine the merit-based prospect of full EU membership and its main principles predictability and conditionality, the mutual trust and confidence necessary for the accession process to be able to deliver its potential, while, on the other hand, having in mind the Western Balkans landscape, these issues have the potential to create serious instability which may be forestalled only by strict rule of law conditionality that will place the focus on the real problems of these societies. To overcome the absorption capacity issue and enlargement impasse, the EU must explore all avenues for the advanced integration of the Western Balkans in the period preceding accession in line with its commitments for phased-in accession as defined in the new methodology while maintaining the central role of rule of law conditionality.

Credibility is the core resource of both pre-accession but also post-accession compliance. With regard to the rule of law, EU credibility should also be reinforced on the inside with the development of mechanisms for protecting its internal dimension and strengthening the sanctioning power of EU institutions. Rule of law reforms are lasting phenomena that do not stop with rule adoption but require genuine internalisation of EU values and standards, thus demanding sustainable efforts for further compliance after the official date of accession not only in terms of main- 
taining the status-quo but also contributing to (lifting) the rule of law state of the Union and advancing the European integration process that strives to approach the idea(l) of a Union based (solely) on the rule of law. It seems that if the rule of law is as important as has been emphasised with regard to its external dimension within the enlargement policy, then steps should be made to establish some 'type' of uniform conception as a common value that would also support its promotion in the accession process and increase the attractiveness of the final reward.

Finally, the multi-layered process of European integration includes both the Europeanisation of the Western Balkans and the process of internal reforms of the Union for the admission of these countries as full EU members. The EU accession process is the only tool for the Western Balkans to become 'European' in terms of values and standards, including the rule of law. If the EU continues to be composed of Member States which do not uphold the rule of law, it is hard to expect them to upgrade the rule of law on the outside and prioritise EU interests over national interests. Thus, this paper has confirmed the clear and close interrelation of the internal and external dimension of the rule of law - its protection within the Union and the ability to deal with internal backsliding on the one hand, and the promotion of the rule of law in the enlargement policy and the projection of this core EU value beyond, on the other. This in turn will strengthen the Union on the inside by reinforcing the EU role as a global player.

\section{(C) $(1) \Theta$}

This work is licensed under the Creative Commons Attribution - Non-Commercial - No Derivatives 4.0 International License.

Suggested citation: L Ognjanoska, 'Promoting the Rule of Law in the EU Enlargement Policy: A Twofold Challenge' (2021) 17 CYELP 237. 